Illinois State University

ISU ReD: Research and eData

Theses and Dissertations

9-26-2017

\title{
Spit Shined And Polished And Ready For College: A Critical Race Analysis Of Program Directors' Perspectives On The Contexts Of College Access Programs
}

Jillian Havard

Illinois State University, jlhavard@hotmail.com

Follow this and additional works at: https://ir.library.illinoisstate.edu/etd

Part of the Education Commons

\section{Recommended Citation}

Havard, Jillian, "Spit Shined And Polished And Ready For College: A Critical Race Analysis Of Program Directors' Perspectives On The Contexts Of College Access Programs" (2017). Theses and Dissertations. 790.

https://ir.library.illinoisstate.edu/etd/790

This Dissertation is brought to you for free and open access by ISU ReD: Research and eData. It has been accepted for inclusion in Theses and Dissertations by an authorized administrator of ISU ReD: Research and eData. For more information, please contact ISUReD@ilstu.edu. 
SPIT SHINED AND POLISHED AND READY FOR COLLEGE: A CRITICAL RACE ANALYSIS OF PROGRAM DIRECTORS’ PERSPECTIVES ON THE CONTEXTS OF COLLEGE ACCESS PROGRAMS

\author{
Jillian Havard
}

102 Pages

College access programs work to prepare underserved students for college admission and enrollment. It is important to identify how the assumptions of college access program leaders affect their common practices and implementation of programs serving African American students, as well as to identify the tensions that exist among theory, research and practice in the college access field. This qualitative study explores the perspectives of college access program directors on the contexts of college access program. Using critical race theory as a theoretical framework, the impact of whiteness, perpetuated by the college access of ideology, is examined.

KEYWORDS: College Access, College Readiness, Critical Race Theory, Cultural Capital, Deficit Thinking, Whiteness 
SPIT SHINED AND POLISHED AND READY FOR COLLEGE: A CRITICAL RACE ANALYSIS OF PROGRAM DIRECTORS’ PERSPECTIVES ON THE CONTEXTS OF COLLEGE ACCESS PROGRAMS

JILLIAN HAVARD

A Dissertation Submitted in Partial Fulfillment of the Requirements for the Degree of DOCTOR OF PHILOSOPHY

Department of Educational Administration and Foundations

ILLINOIS STATE UNIVERSITY 
(C) 2017 Jillian Havard 
SPIT SHINED AND POLISHED AND READY FOR COLLEGE: A CRITICAL RACE ANALYSIS OF PROGRAM DIRECTORS’ PERSPECTIVES ON THE CONTEXTS OF COLLEGE ACCESS PROGRAMS

JILLIAN HAVARD

COMMITTEE MEMBERS:

Pamela Hoff, Co-Chair

Mohamed Nur-Awaleh, Co-Chair

Beth Hatt

Karla Martin 


\section{ACKNOWLEDGMENTS}

I am so very grateful to my mom, Diana Havard and my sister, Johnnie Watkins, for their support and sacrifice throughout my educational journey. It is their strength and love that has motivated, nurtured and sustained me to this point. To my committee, you are appreciated more than words can express. Dr. Hoff challenged me to become a bold critical scholar and served as a wise and patient guide along my quest. Dr. Hatt offered correction and expert insight with unfailing kindness. Dr. Mohamed fine-tuned my style and scholarship. Dr. Martin was a safeguard for my critical voice. I am humbled by their support. Last, but not least, I must thank my family and friends for listening ears, encouraging words and godly tolerance throughout this process. Thank you, Robbie, Larry, Toni, Earvin, Herman, Iris, Marilyn, Nicole, Shanna, Khalia, Devon, Lupe, Tuwana and “the cousins."

I dedicate this work to John and Johnnie Mae Lawrence, and Mark and Dorian Lawrence - the before and after.

J.H. 


\section{CONTENTS}

Page

ACKNOWLEDGMENTS

CONTENTS

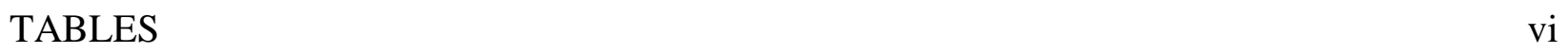

CHAPTER I: INTRODUCTION 1

The Birth of College Access $\quad 5$

$\begin{array}{ll}\text { Philosophical Assumptions } & 11\end{array}$

$\begin{array}{ll}\text { Statement of the Problem } & 12\end{array}$

$\begin{array}{ll}\text { Purpose of the study } & 15\end{array}$

$\begin{array}{ll}\text { Research Questions } & 15\end{array}$

$\begin{array}{ll}\text { Conceptual Framework } & 16\end{array}$

$\begin{array}{ll}\text { Critical Race Theory } & 16\end{array}$

$\begin{array}{ll}\text { Conclusion } & 17\end{array}$

CHAPTER II: LITERATUE REVIEW 19

$\begin{array}{ll}\text { Introduction } & 19\end{array}$

College Access Ideology 19

College Access Theoretical Perspectives $\quad 22$

$\begin{array}{ll}\text { Deficit Thinking } & 23\end{array}$

$\begin{array}{ll}\text { Social Capital } & 27\end{array}$

$\begin{array}{ll}\text { Cultural Capital } & 29\end{array}$

$\begin{array}{ll}\text { Cultural Wealth } & 30\end{array}$

$\begin{array}{ll}\text { College Access Students } & 31\end{array}$ 
First-Generation Students

College Access and Whiteness

Academic Preparation

Acculturation

Support Networks

Conclusion

CHAPTER III: METHODLOGY

Introduction

Purpose of the Study

Research Questions

Qualitative Techniques

Data Collection

Recruitment

Statement of Positionality

Data Analysis

Trustworthiness

Conclusion

Participant Profiles

Sam

Peter

Rochelle 
Mark

Introduction

Research Question 1A

Composite of Blame

Achievement Gap.

Low-income.

First-generation.

African American Students.

Research Question 1B

Road to Redemption

Acadmics.

Cultural Exposure.

Research Question 2

Principles of Pathways

Gatekeepers.

Social Support Net(worth).

Mentors.

CHAPTER VI: CONCLUSIONS

Discussion

Implications 
$\begin{array}{ll}\text { Future Directions } & 89\end{array}$

$\begin{array}{ll}\text { Future Research } & 89\end{array}$

$\begin{array}{ll}\text { REFERENCES } & 91\end{array}$

$\begin{array}{ll}\text { APPENDIX A: INTEERVIEW PROTOCOL } & 100\end{array}$

APPENDIX B: RECRUITMENT EMAIL 102 


\section{TABLES}

Table

Page

1. Program readiness goals and activities by participant 


\section{CHAPTER I: INTRODUCTION}

They walked along the front of the school and passed the main entrance. There were three bronze plaques over the triple doors.

I am the way out of the city of woe

I am the way to a prosperous people

I am the way from eternal sorrow

Chico and the Raiders had spray-painted their insignia over the middle plaque:

Sacred justice moved my architect

I was raised here by divine omnipotence

Primordial love and ultimate intellect

“You know, Shit,” Willie said, looking up at the last bronze plaque -

Only the elements time cannot wear

Were made before me, and beyond time I stand

Abandon ignorance, ye who enter here

-then down toward Linden Hills, "I could have done all right if I had gone to school."

"You're doing all right now."

"Naw, I mean I could have been a doctor or something. You know I have six hundred and sixty-five poems memorized in here - six hundred and sixty-five, and lots of 'em ain't mine. I have all of Baraka, Soyinka, Hughes, and most of Coleridge. And Whitman - that was one together dude. My mom says with a memory like that, I could have breezed through med school."

Lester didn't say anything for a moment, but then he stopped walking and pulled at the chain fence. "Ya ever wonder why they put fences around these schools, White?" 
“Huh?” Willie had been lost in thought.

"I mean, you can see it with an elementary school 'cause the little kids might run out in the street without thinking or something, but why around a junior high school and high school? It's not to keep people out, 'cause the gate's always open and sometimes even stray dogs wander in. Remember the time that mutt came in and we tied Miss Thatcher's math book to its tail and ran all over the school yelling, 'Yeah, Miss Thatcher's finally gone to the dogs'?”

Willie smiled. "What ya getting at, Shit?"

"Fences, White, fences. Even at the university: big stone fences - and why? The gates are open, so it's not to keep anybody out or in. Why fences?" He looked at his friend's blank face. "To get you used to the idea that what they have in there is different, special. Something to be separated from the rest of the world. They get you thinking fences, man don't you see it? Then when they've fenced you in from six years old till you're twenty-six, they can let you out because you're ready to believe that what they've given you up here, their version of life, is special. And you fence your own self in after that, protecting it from everybody else out there. 'You wanna be a doctor? All the books are in the library. Why can't you just go and read them, sit for an exam, and get an internship? No way, right? Why? 'Cause they gotta get you inside that fence. You gotta get that mark on your forehead and that print in the palm of your hand that you've sat through the philosophy and history and crap that goes along with it. They gotta be sure that when you go out among the real people, your fences are all intact. Then when you move to Linden Hills, or wherever, you're gonna stay put and help vote out radicals and heave a sigh of relief when you read that a Panther got it in the back from an L.A. cop... “And these folks refuse to get this stream filled up, but they'll spend money to keep this banister repaired.” 
"Well, because of the school. I heard two white kids drowned here once."

“Willie, they don't give a damn about them kids. None of their children go that school now. It's what I been telling you before - it's a them and us thing - it's a fence, man. Just another fence...

\section{-Linden Hills, Gloria Naylor}

In serving as a bridge to college for underserved students, college access programs operate with the assumption that once students are properly prepared for college, they will be assured college success. The field of college access covers a plethora of activities designed to steer students towards degree attainment. However, this study focuses on college access programs designed to enhance and supplement the regular school activities of minoritized and low-income youth while assisting with college admission (Corwin, Colyar \& Tierney, 2005). These programs have also been known as college preparation programs or college bridge programs. This study explores how deficit thinking is woven into college access programs' missions and objectives, as well as how it affects the intended outcomes to increase the college success of underserved students, identified as low-income and African American. The overlapping identity of race and class among students served within college access programs is termed by critical race theory (CRT) as intersectionality (Delgado \& Stefancic, 2012).

Higher education institutions were not created to serve poor students or students of color, and have a long history of limiting access to these students. Yet, earning a college education is idealized as one of the keys to achieving the American dream through hard work. Challenging this notion, Patton (2016) asserts:

Popular rhetoric suggests higher education is the great equalizer and affords life opportunities, particularly to those who, regardless of circumstance, "work hard.” This 
meritocratic discourse is laced with racist and classist assumptions that ensure hard work alone is insufficient for marginalized groups to excel. This discourse attaches nobility to higher education without examining its contributions to the inequality it purports to disrupt. (p. 318)

Economic growth and development for individuals, as well as society overall, has been cited by Heller (2013) as a benefit of higher education. However, for many African American, low socioeconomic status (SES) and first-generation students, the option to achieve a postsecondary education is out of reach. Thus, greatly limiting access to the supposed American dream for these students. In response to this limited access, college access programs aim to provide information to increase the opportunities for underserved students to enroll in college. Yet, given programs designed to increase the enrollment these students, of those who do enroll, only a small percentage attain a four-year college degree (Perna, 2005; Perna \& Kurban, 2013). In getting students ready to attend college, college access programs focus on molding students to fit in. A mission to serve the student population labeled as "at-risk" and 'disadvantaged" permeates college access practice, research, theory and policy. These labels and subsequent tactics to serve these students are steeped in deficit thinking and victim blaming (Valencia, 2010).

There continues to be a disparate representation between the numbers of African Americans enrolled in higher education as compared to the enrollment of white students (Ishitani, 2006; Karen \& Dougherty, 2005; Perna, 2005; Perna \& Kurban, 2013) and racial and social class strata continue to negatively impact postsecondary education (Bergerson, 2009; Heller, 2013). Poorly funded schools and inadequate resources during K-12 education inhibit African Americans, first generation and low SES students from access to effective higher education pipelines. Academic preparation has been identified as a key indicator of college 
success (Perna \& Kurban, 2013), yet poorly funded school districts, attended by many underserved students, namely African Americans, frequently lack the resources and infrastructures necessary to prepare students academically for postsecondary education (Carter, 2005; Kozol, 2012; Lleras 2008). Researchers and scholars have enacted a CRT approach to call out and push back against the effects of deep-rooted of racism within U.S. postsecondary institutions, on college access and college outcomes for African American students (Patton, 2016; Yosso, 2005).

The differences in the quality of life and civic participation of college graduates in relation to non-graduates exemplify the gains of earning a college degree. Research supports the notion that higher education affords its graduates higher pay, increased job satisfaction, and employment stability, with college graduates earn much higher salaries on average than nongraduates (Karen \& Doughtery, 2005; Heller; 2013). College access programs present as a pipeline to college and career success, underscoring the meritocracy ideal, challenged by CRT (Patton, 2016). The goal that the earliest college access program, TRIO Upward Bound, set out to achieve was to provide educational opportunities to enhance the earning potential of lowincome students. In fact, education was identified as one of the solutions proposed to provide opportunities to the so-called disadvantaged at the onset of the 1964 War on Poverty (Levine, 1970; Long, 2013). Hence, Upward Bound was created to bridge the gap between poverty and opportunity.

\section{The Birth of College Access}

The earliest college access program is the federal Upward Bound program which was created via the 1964 War on Poverty legislation. Levine (1970) offers an analysis of the events leading to the War on Poverty and the resultant legislative actions. He also details the political landscape 
leading up to and the early days of the legislation that led to the formulation of Upward Bound. The day after President Kennedy's assassination, President Johnson received information regarding Kennedy's interest in a coordinated antipoverty effort. President Johnson was eager to proceed with these efforts, and during his January 1964 State of the Union Message, President Johnson declared war on poverty. Johnson appointed Sargent Shriver as the chairman of the task force charged to move forward with plans to address poverty related issues. The activity of the task force was fast, widespread, and well-funded. The programs and legislation were motivated by the ideology that the plight of the poor could be alleviated by tackling the apparent deficiencies that inhibited their ability to take advantage of opportunities for economic gain. As a result, the Office of Economic Opportunity was created to provide federal interventions into social inequities.

The War on Poverty birthed programs aimed at increasing the capacity of individuals to engage in opportunities for employment and education. "With a combination of financial aid and college preparatory programs, these programs were the first major step to making mass higher education possible for all Americans,” (Long, 2013, p. 93.). The projected outcome was the provision of avenues for the economically disadvantaged to gain skills and education to even the playing field for entrance into the workforce and to pursue educational advancement. The Economic Opportunity Act was implemented as part of the War on Poverty declared by the Johnson administration. The Economic Opportunity Act was passed on August 20, 1964, and established legislation to create programs aimed at increasing social opportunity for the poor and disadvantaged. Programs such as Job Corps (Title I), College Work-Study Program (Title I), Community Action Program (Title II), Adult Basic Education (Title II), Rural Loan Program (Title III), Small Business Development Centers (Title IV) and Work Experience (Title V) and 
VISTA-Volunteers in Service to America (Title (VI) were developed to equalize opportunities for the poor. Levine (1970) purports that there were two competing objectives of the War on Poverty. One being antipoverty and the other equal opportunity. In quoting an excerpt from the Economic Opportunity Act of 1964, Levine (1970) writes:

The United States can achieve its full economic and social potential as a nation only if every individual has the opportunity to contribute to the full extent of his capabilities and to participate in the workings of our society. It is, therefore, the policy of the Unites States to eliminate the paradox of poverty in the midst of plenty in this Nation by opening to everyone the opportunity to work, and the opportunity to live in decency and dignity. It is the purpose of this Act to strengthen, supplement, and coordinate efforts in furtherance of that policy. (p. 12-13)

The author offers a critique of the Economic Opportunity Act of 1964, asserting that there is an absence of the definition of poverty, and additionally both antipoverty and equal opportunity are intertwined throughout the law. The idea that poverty was propagated by poor people's lack of decency and dignity, and failing to contribute to their full capabilities exonerates the United States government, and policy makers, from any onus related to the social inequities. Little effort was made to examine the limitations of the education system and workforce culture that presented barriers to access and advancement. Instead, politicians acted on the assumptions that the poor could achieve a better standard of living through participation in social and educational compensatory programs.

College access programs were developed in response to a disproportionately low number of underserved students enrolled in college. As a means to increase the opportunities for underserved students to enrollment, the federal government intervened (Levine, 1970; Long 
2013). The Office of Economic Opportunity implemented TRIO to foster equal opportunities for all Americans. In response to the changing climate of socioeconomic status and race relations, the intent of TRIO was to provide leverage to those who were historically marginalized. However, by creating programs to leverage the opportunities of the economically disadvantaged, politicians failed to acknowledge structural components that affected the long term marginalization of said population. Instead, the focus was on improving the deficiencies of those who had been essentially locked out of opportunities for advancement. Long (2013) describes President Johnson's motive in creating TRIO programs as a means to ”... improve opportunities for low-income students by investing in college preparation programs geared toward firstgeneration and other disadvantaged high school students” (p. 93). While in fact, centuries of systemic discrimination and segregation (Menchaca, 1997) had created an ethnocentric culture that served as a barrier for minorities to obtain entrance into the ivy towers. Furthermore, recent reductions in funding for the programs that serve to leverage opportunities for these students has limited the breadth and reach of current programs.

The 1964 War on Poverty prescribed individual level programming to cure structural level problems. Prior to this time, legislation- such as the 1962 amendments to federal welfare laws, was enacted to provide job training and special services to people in need (Levine, 1970). These plans to uplift the economically disadvantaged by assisting them in getting off welfare and into the workforce required programs that would fix the poor. Educational access was a key component of these programs. Long (2013) argues that the federal interventions into higher education via the War on Poverty were a response to the realization that education was key to sustaining economic prosperity. The focus on education as a means to boost the country's economic situation divulges that the programs beget by the War on Poverty were designed in the 
spirit of self-interest, as a benefit to the larger society. This is a clear instance of what Bell (1980) describes as interest convergence. Bell (1980) posits that interest convergence occurs when the majority implements policies to uplift the minority as an act of self-interest that will concurrently benefit, or elevate, the majority. During the War on Poverty, the availability of higher education access and funding to those deemed disadvantaged, became of import to policymakers once it became apparent that it would benefit the economy. This is akin to the interest convergence that is apparent in Woodson’s (1998) discussion of higher education opportunities for freedmen, "The more liberal colonizationists endeavored to furnish free persons of color the facilities for higher education with the hope that their enlightenment would make them so discontented with this country that they would emigrate to Liberia (p. 158).” In both instances, education for African Americans only became a priority when it was deemed to benefit those in power. Yet, these efforts were packaged in policies and practices that, while causing those in power to appear benevolent, ignored the fact that the supposed deficits that required correction, had been caused by racist power structures that previously denied said opportunities to those said to benefit from such efforts.

While the predominance of the programs set in place by the Office of Economic Opportunity was focused on transforming the poor into a trained workforce, education programs such as Head Start and Upward Bound were intended to offset the under-resourced elementary and high schools attended by low-income and minority students, and increase their educational capabilities. Upward Bound was designed for students who could not afford college and were academically underprepared. Furthermore, there was an intent lend a helping hand to students from families with no relatives who had never attended college, or first-generation students. The program uses compensatory education to provide equal opportunity for these students to enroll in 
college. In a discussion of the effects of the War on Poverty, Long (2013) asserts that barriers to college access for low-income students continue to be greater than for those students from other groups.

There are structural inequities that prevent the equal opportunity to education (Corwin, Colyar \& Tierney, 2005). These inequities are visible in the social, political and philosophical factors that have laid the framework for higher education. Thus, creating systemic roadblocks for low-income and minority students who lacked access to the higher education institutions at their inception. Higher education institutions have a tradition of social networking that has systematically marginalized and denied equity to underserved students. Specifically, first generation students who have not been plugged into the network of generations of relationship building cum social capital are left out in the cold. When writing of the social function of $18^{\text {th }}$ century higher education, Vine (1976) reports Benjamin Franklin as stating that the right schools could provide connections which were essential for success. Vine (1976) describes how students used college as a venue to leverage said connections into social networks. Traditionally, the social networks formed during college established social and professional connections which led to securing such social capital as entre into upper echelon families and coveted employment opportunities. The social knowledge associated with postsecondary education was not an overt component of the curriculum, yet it was quite commonplace. The access to social networks defined by connections and insider knowledge, also cultivated cultural capital via experiences relegated to the educated elite. The social component of 18th-century postsecondary education, discussed by Vine (1976), has had a strong residual effect on modern higher education. Students identified as nontraditional and underserved enter college sans a legacy of the social and cultural experiences that are esteemed and valued as capital. 


\section{Philosophical Assumptions}

The political and social climate that birthed college access programs heralded that those who were economically disadvantaged lacked equal opportunity to access resources, failing to acknowledge the longstanding institutional practices that systematically excluded underserved students from successfully obtaining a postsecondary education (Patton, 2016). Efforts to include these students are often undermined by victim blaming language such as labeling them disadvantaged. Moore (2001) suggests that the term economically disadvantaged be replaced with the term economically exploited. This shift in language will serve to remove the blame of the effects of poverty from the victims to the systemic problems that created and continue to sustain cycles of poverty. Moreover, within the college access arena, this shift can serve to release students from the burden of actively working to correct cultural deficits as a means to being college ready. Use of the term economic exploitation loosens the grip of cultural deficit thinking towards African American students, and acknowledges that these students have been systematically denied resources that the dominating culture deems valuable, yet are shrouded in exclusivity.

Centuries of deficit thinking actualized via racist policies and legislation hindered minorities in the pursuit of opportunities commonly afforded whites (Valencia, 1997). One such example of the institutional barriers were the compulsory ignorance laws preventing Blacks from being taught to read (Menchaca, 1997). Centuries of racist laws rooted in beliefs in the inferiority of minoritized people and mandated segregation can be traced back to the foundations of United States government. While colleges and public education systems were educating whites, the humanity of minorities, specifically Blacks, which questioned whether they could be educated. 
The ideas behind the creation of college access programs are rooted in the belief that these students lack resources and thus abilities for college access. The answer thus becomes implementing deficit programming designed to change the student (or augment the student experience), rather than examining postsecondary institutions and the need to shift to practices that embrace the experiences of students who are faced with hindrances to access. This approach is fashioned after the ideological predecessor of current college access programming, Upward Bound. This deficit programming places the onus of success, or lack of success, on the student, and completely exonerates the institution, or the institutional culture, of all responsibility. Postsecondary institutions have ignored the need to embrace the experiences and cultures of a diverse student body while restricting students to a one size fits all college experience. Research on college preparation has extensively examined how to develop college access programs which can adequately equip students with cultural knowledge as well as academic preparation. Much of this research relies on a deficit theory framework that is fixated on blaming the victim. As scholars pursue a heterodoxic research approach towards liberating those who have been systematically denied opportunities, many issues need be addressed. Specific issues include how college access administrators and universities which house access programs can employ leadership, as well as finance models and strategic planning that best serves to increase the admission and degree attainment of underserved students. There currently exists no normative model for college preparation.

\section{Statement of the Problem}

Degree attainment for African Americans enrolled in institutions of higher education is disparately lower than that for white students (NCES, 2017). African Americans face a plethora of obstacles and barriers to college enrollment and degree attainment. The obstacles affecting 
college access have been identified by scholars as a lack of academic preparation (Perna, 2005), limited financial resources and assistance (Perna \& Kurban, 2013) and unfamiliarity with the college enrollment process (Conley, 2008). An additional obstacle lies in the negligence of institutions of higher education in creating a welcoming and inclusive environment where African American students’ culture is embraced (Patton, 2016; Welner \& Carter, 2013). More often there is a system of covert reminders of students' cultural differences juxtaposed to the norms of the dominating culture. Additionally, institutional policies and procedures either implicitly or explicitly blame these students for their failure to get in and fit in. These policies include remediation courses, where students are called out for not meeting academic standards and must sink or swim to prove their aptitude to succeed in college. Also, students are sorted into campus programming for "at-risk" or "disadvantaged” students. This labeling resounds of deficit language steeped in victim blaming (Valencia, 1997), and releases colleges and universities from the onus of acknowledging the effects of systemic racism on African American students' matriculation and college experiences. College access programs have been prescribed as the solution to increase the college enrollment of underserved students, including African Americans (Bergerson, 2009; Conley, 2008; Corwin, Colyar \& Tierney 2005; Perna \& Kurban, 2013; Walpole, 2008;). These programs operate at the levels of community-based organizations, university-based programs, and/or federally funded programs.

Research on college access programs has been extensive. While scholars have explored program outcomes, thus proliferating theory to improve best practices, the discussion has been dominated by quantitative studies on student outcomes, and qualitative studies telling of student experiences. Research centered on student outcomes and student experiences (Bergerson, 2009; Hagedorn \& Fogel, 2002; Reid \& Moore, 2008) have neglected the perspectives and insights of 
college access program directors charged to shape program contexts. Scholarship examining contexts have been focused on college access and preparation within high schools (Engberg \& Wolniak, 2010; Farmer-Hinton, 2011; Farmer-Hinton \& Adams, 2006).

Swail (2005) reports that “...states and local governments spend millions of dollars on special programs to facilitate academic preparation and college access for underrepresented students (p. 175).” Funding for these programs traditionally supports academic preparation, college choice assistance and the dissemination of financial aid information to increase access. While funding guidelines set parameters for the implementation of college access programs, college access programs vary by delivery model, administration, leadership, sponsorship, and governance. While there exist standard tenets of college preparation such as academic preparation and financial aid information, program autonomy allows for variability in overall program design. Swail (2005) discusses the role of context in the success of college access programs, asserting "Rather than pursuing the question 'What works? It might be more useful to ask, 'What works where, with whom, under what conditions and why' (p. 198)?’ The efficacy of college access programs in aiding in participants' college enrollment is grounded in their abilities to meet the varying needs of the students that they serve. While academic preparation, financial aid information, and admissions assistance are vital elements to enrollment, the elements that lead to college success and degree attainment are not easily pinpointed.

It is the role of college access program leaders to plan and implement activities in accordance with program missions and objectives. Programming may be influenced by the culture of the constituency that is served, the expectations of the sponsors, donors and boards of directors, or the experiences of the key administrator. The abundance of research on college choice, college transition, and academic preparation as related to student variables reveals only a part of the 
college access narrative. The story is incomplete absent of the program directors' perspectives on how they apply resultant theories to practice. These perspectives are needed to broaden the discussion on contexts within college access research. This inquiry explores how decisions and best practices, of program directors, are informed and implemented. The scope of this inquiry focuses on the contexts of college access programs where African American students are served. Illuminating the experiences of program administrators is effective in challenging the heterodoxic beliefs that inform and undergird college access research, funding, and programs. It is necessary to approach this inquiry using a constructivist lens, as the study of this problem provides an understanding of the unique views of program directors in serving the needs of African American students as they prepare to go to and through college.

\section{Purpose of the study}

The purpose of this study is to identify how the assumptions of college access program leaders affect their common practices and program implementation in serving the needs of African American students. In addition, the tensions that exist among theory, research and practice in the college access field are examined.

\section{Research Questions}

The following research questions guided this study:

1. What are the underlying assumptions that college access administrators have about the African American students that they serve? How do these assumptions play out in the actual practices of the program services?

2. How do the explicit goals of college access programs align and/or contradict with the actual practices of the programs? 


\section{Conceptual Framework}

\section{Critical Race Theory}

Critical race inquiry in education has developed as a way to identify the tensions that exist between the rhetoric of educating African American students and how educational practices are actually implemented. For this study, I utilized the CRT lens in concert with qualitative research methods to convey the narrative of the college access program directors through their own stories while unearthing the tensions between program goals, director's assumptions, and students' needs.

In defining critical race theory (CRT), Ladson-Billings (1999) declares that CRT seeks to expose the racism that is naturally embedded within American culture. The author further contends that experiences of oppressions, including racism and sexism, are of import to researchers' development of a CRT analytical standpoint. CRT also serves as a critique of liberalism, specifically the lack of mechanisms to enact the changes necessary to address racism. I use critical race theory as a liberating paradigm. As a research lens, CRT is driven by the goal of empowering the oppressed through liberation from the constructs of race, class, and gender. Delgado and Stefancic (2012) discuss the debate of "whether race or class is the dominant factor in the subjugation of people of color (p.120)." They go on to state that CRT scholars have not developed "a comprehensive theory of class (p. 120)" and that "a general theory of race and economics remain elusive (124)."

The research on college access has supported a compensatory approach from its inception. The notion that the disparity of degree attainment for African Americans can be alleviated by adding to or changing the student has been the guiding assumption. The CRT lens guides my critical ethnomethodology in dissecting the issues related to program leaders' 
assumptions and perceptions about meeting African American students' needs within the context of college access programs. Merriam (2009) defines critical research as focusing on the systems and institutions that shape educational practice. College access programs rely on funding from sources that rely on research. Research is guided by epistemologies or embedded knowledge truths that are embedded into the methodologies (Crotty, 1998). The research on college access is steeped in deficit epistemology that focuses on fixing the students rather than the higher education institutions that these students seek to attend. Research on college access programs upholds college as a prime route to assimilate African American students to the dominating white culture. The historical contexts that birthed college access programming, amidst the War on Poverty, delineate such programs as gateways from poverty to the proverbial American dream. Critical race theory is an optimal lens to unravel and redirect the victim blaming college access research that is steeped in deficit theory.

Ladson-Billings (1999) cites the use of voice as a means of critical race theory to link form and substance to scholarship. The voices of college access program directors' regarding assumptions about students that they serve and perspectives on best practices are presented in this study. It is necessary to connect theoretical and ideological beliefs to the implementation and delivery of college access programming. Thus, this study utilized qualitative research and analysis through a CRT lens, in an endeavor to adjoin the voice of college access practitioners with the prolific efforts of academicians to explore the essential elements of programs in effectively preparing low-SES African American students for college.

\section{Conclusion}

There are currently a wide variety of college access programs available to assist African American students on the pathway to college. Yet, there exists no model of delivery or any 
clearly identifiable set of best practices. Thus, it is important to determine the factors that influence program directors on the planning and curricula of college access programs. It is important to determine the efficacy of college access programs in preparing students for college. There is currently a lack of evaluative data to explain effective designs of college access programs (Corwin, Colyar \& Tierney 2005 Perna, 2005). An analysis of the motivating assumptions and practices employed by college access programs directors will promote an understanding of the best practices as well as challenges in assisting in the transition to postsecondary education for African American students. 


\section{CHAPTER II: LITERATUE REVIEW}

\section{Introduction}

In this chapter, I use a literature review to address the ideology of college access programming and the epistemologies that frame college access research. Although there is no normalized model for college access, there is an established and accepted ideology of college access across research and practice. I contend that the accepted ideology is inherently flawed, as it perpetuates the marginalization of the identities and cultures of African American students. As such, I examine the epistemologies of access research and the guiding ideals of college access programs. Such as is prudent in understanding the motivational factors of college access programs functioning to meet the needs of African American students. My central focus is the contexts of college access support programs that operate outside of traditional school settings. I will discuss the needs of African American students, as delineated by college access research, as I reveal how the ways in which these needs are classified enforce victim blaming and diminish the role of the higher education system in creating and sustaining road blocks to access. Finally, the functions of access programs in advancing notions of whiteness will be addressed.

\section{College Access Ideology}

For many of African American students, college access programs present unique opportunities to access knowledge and assistance regarding the academic and technical requirements for admissions to institutions of higher education. College access programs assist students on the college pathway, and optimistically place them among the academically trained workforce, and moreover in receipt of the trappings related to success. Thus, supporting the notion that a college degree leads to the achievement of the "American dream.” Patton (2016) challenges the meritocratic discourse that positions higher education as the great equalizer 
affording opportunities for those who work hard enough to achieve them. Patton states that this discourse ignores the role of higher education in perpetuating the inequities that it claims to conquer. College access programs also uphold this myth. The myth of meritocracy serves to sustain the ideals of college access, and implies that if students labor to better themselves they will be ready to enter college and realize the American dream.

College access research overtly lists ways in which students can labor to be college ready, with a primary focus on self-improvement measures. In a review of essential components of college access programs, Bergerson (2009) notes that it is essential for programs to focus on developing intellectual skills needed for college. Bergerson (2009) supports her discussion referencing the work on "cultural scaffolding” offered by Corwin, Colyar and Tierney (2005). Corwin et al. (2005) acknowledge the structural and cultural constraints in the educational system that impede access, but also argue that emphasizing the culture of the student is” helpful, but not critical” (p. 3) to college access programming. The prevailing crucial components of the college access ideology center on augmenting student deficiencies in the areas of academics, ability to access and process information, culture, and self-efficacy (Conley, 2008; Corwin, Colyar \& Tierney,2005; Bergerson, 2009; Enberg \& Wolniak. 2010). Further suggestions to remedy the access problem include supplementing students 'cultural and academic capital (Hagedorn \& Fogel, 2002), and outline additional internal barriers that create disadvantages for students, e.g. lack of parental knowledge of the college application process and lack of academic preparation (Reid \& Moore, 2008). Bouffard and Savitz-Romer (2012) suggest a developmental approach where students are gradually influenced to see themselves as "college material" (p. 42). These discussions discount the cultural wealth (Yosso, 2005) of the students that college access programs serve. In confirmation, Welton and Martinez (2013) state, “...college readiness 
research places emphasis on policies, programs, and practices that tout to remedy deficiencies instead of building upon the prevailing assets of students from underrepresented groups (p. 201).” The aforementioned remedies are research based and purport alignment with positive college access outcomes. Yet they offer victim blaming solutions, and relieve colleges and universities of acknowledging systemic racism that hinders equitable access, as well the need to do the work to develop culturally inclusive campus environments.

College access for low-SES and minoritized students has been prolifically researched. Yet, much of the scholarly work in the area of college access is predicated on deficit thinking, which Valencia (2010) defines as remedies aimed at improving internal deficiencies of those who are suffering from the ills of social problems - such as access to college. College access is considered a social problem as it is prescribed to increase social mobility for the supposed disadvantaged. In response to this social problem, much of the work in college access fosters a victim blaming (Valencia, 2010) approach that ignores systemic racism along the P-12 pipeline, and issues of classism that encumber educational equity for African American students necessitating college access assistance. College access research, policy and programming have remained grounded in the founding principles of Upward Bound, the prototype that set the stage for college access work. These principles support creating equal opportunities, to fix the problem of the poor (Levine, 1970), by offering assimilation to the dominating culture's standards of success as solutions.

Early college access programming emerged from the policies related to the 1965 War on Poverty with a goal to provide equal opportunities to low-income citizens (Levine, 1970; Long 2013). Still generations later such programs have multiplied in number and type, while the numbers in college enrollment and degree attainment, by ethnicity, remain disparate. NCES 
(2017) data reports that bachelor's degree attainment for African Americans is 19\%, while at 54\% their white counterparts. This gap in degree attainment exemplifies the need for effective college access support for African American students. Furthermore, these statistics point to a significant hindrance toward bachelor’s level career opportunities, for African Americans. The job market for the college educated continues to become more competitive, creating an everincreasing need for an academically trained workforce. Yet, many African American students are left academically unprepared, as a result of school failure (Valencia, 2010) and ae not given adequate information on the pathways to college (Welner \& Carter, 2013). The need for college access program is evident. However, the onus of problems associated with academic preparation and information about college lies with systemic hindrances within in the educational system, not the students. The college access ideology advances notions of deficit thinking with a focus on student level improvements and interventions.

\section{College Access Theoretical Perspectives}

It is not possible to discuss college access without closely examining the theoretical perspectives that have motivated the rationale and design of college access programs as an avenue to promote opportunity. College access programs are influenced by the epistemological and theoretical perspectives of researchers, policy makers and practitioners (e.g. staff, directors, mentors). Merriam (2009) asserts that a theoretical framework is the system of concepts, expectations, beliefs, assumptions, and theories that inform research. As these assumptions underpin the college access ideology, it is practical to consider how the prevalent epistemologies of the college access research agenda materialized.

Deficit thinking (Valencia, 1997; 2010) has bled into the theoretical lenses of college access scholars and has been overlooked as a possible hindrance to the advancement of 
discovering solutions. The scholarly discourse around college access is primarily centered on social capital and cultural capital theoretical frameworks. However, additional theories to challenge the former been identified. Community cultural wealth (Yosso, 2005), which promotes awareness of the needs of the individual student, is one such alternative to commonly used theoretical frameworks. Cultural wealth has been advanced as a theoretical lens within college access research (Bergerson, 2009; Swail, 2005; Villalpando \& Solorzano, 2005) but has not prevailed to eradicate deficit based discourse and practices. Welton and Martinez (2014) assert, "Comprehensive college access and readiness literature fail to consider the reality - one that is often met with subordination and racism- SOC [students of color] face in the pipeline to college (p. 218).”

\section{Deficit Thinking}

Valencia (1997) discusses the ways in which deficit thinking has inundated discourse regarding the educational achievement of minorities. Deficit thinking assigns school failure to internal deficits of students. Deficit ideology (Valencia, 2010) refers to assumptions of inherent deficiencies based on race, class or ethnicity that cause students to perform poorly in school. These assumptions were constructed using pseudoscientific attempts to validate whites as the superior race, and other races as inferior and thus exposed for subjugation. Deficit ideology comprises six elements; victim blaming, oppression, pseudoscience, temporal changes, educability and heterodoxy. College access discourse is beleaguered by assumptions rooted in deficit thinking. These assumptions are specifically prevalent as related to academic and cultural barriers to college for minoritized students.

Valencia (1997) demonstrates the ways in which the deficit thinking model is associated with school failure. Deficit thinking ideologies blame school failure on internal deficiencies of 
the students - victim blaming. Blaming the victim ignores the culpability of the school system in failing to provide adequate resources for students’ academic preparation. Motivated by a benevolent desire to solve the problem of educational ills, the focus has been on aiding the victim by offering methods for improvement. While focusing on the student, a blind eye is turned on a faulty educational system steeped in systemic racism and discrimination as the cause of school failure. The college access ideology embraced goals for serving African American students, reflect deficit thinking in purporting strategies to improve students' cultural knowledge and experiences. For example, Corwin et al. (2005) suggest that college access programs endeavor to equip students with socialization skills to adapt to college life. This socialization is said to assist students in gaining cultural capital that their peers from higher SES backgrounds naturally wield. The erroneous assumption of African American students’ cultural deficits supports Yosso’s (2005) claim that race in schools (and other academic settings) is coded as ‘cultural difference’ (p. 75). College access programs engage students in cultural activities to supplement 'cultural differences.' Field trips and activities to expose participants to the dominating culture as means of assimilation can serve to teach them to value other cultures above their own. An alternative response is to teach students to value their identity and attributes as a necessary component of diversity and multiculturalism. Woodson (2013) so eloquently asserts,

To educate the Negro we must find out what his background is, what he is today, what his possibilities are, and how to begin with him as he is. Instead of cramming the Negro’s mind with what others have shown that they can do, we should develop his latent powers that he may perform in society a part of which others are not capable. (p. 103) 
Empowerment, rather than acculturation and exposure to the dominating culture will better serve African America n students as they embark on postsecondary journeys.

Menchaca (1997) reveals historical evidence of longstanding views of minorities as inherently inferior and ill-fated to low levels of intellect as well as class standing. Pseudoscientific research detailing the inherent differences between races - going as far as to claim a differentiation in species - has been propagated for centuries. Using methods such as craniology scientists declared that by examining and comparing the skulls of whites and people of color it was made evident that people of color were incapable of higher order thinking or moral behavior without being under the restrictive supervision of whites. Going back as far the founding fathers who wrote the declaration of independence espousing all men to be created equal, people of color were perceived to be inferior. In spite of the fact that these findings have been invalidated, the knowledge that gave rise to deficit thinking continues to be embedded in the policies and culture of modern American society.

The concept of the inferiority of people of color is traced back to 1600s in Menchaca's (1997) critical overview tracking the development of deficit ideologies. Menchaca utilizes a timeline crossing three centuries, while documenting scientific attempts to validate deficit thinking. The scientist and scholars of the time went to great lengths to propagate unsound (and now debunked) rationale to support their views of white people and people of color being from different species and the inherent inferiority of people of color. Over time these views were further used to support slavery, the need for people of color to rely on whites to be properly civilized into the popular culture and to provide evidence that people of color were lazy and savage. 
Slave owners viewed educating Blacks as property damage since there was no place for an educated black person. Yet mission schools were developed where some enslaved people received an education. As a result, compulsory ignorance laws were enacted to prevent blacks from learning to read. Giving way to the justification of deficit thinking with the support of legal and education practices. The ill-founded basis for such laws provides evidence to challenge the notions that blacks were ineducable. Yet, theories that blacks were inherently savage and intellectually inferior continued to fester. The use of white supremacy to deny access to education led to the criminalization of educated African Americans. These laws justified public and private dehumanization and subjugation of African American people. Anthropologists who were of note during this period, provided an academic stance to propagate beliefs of whites as a superior race. This was achieved by utilizing cultural theories touting that people of color were not only biologically inferior but also produced inferior cultures. Unfortunately, these beliefs continue to permeate research professing to support diversity and equity. Assumptions fueled by deficit thinking deny the value and assets of African American cultural wealth. Thereby, positioning the dominating culture as the ideal.

Centuries of theories and pseudoscientific research eventually culminated in Social Darwinism theory and maintained popularly accepted beliefs of the inherent inferiority of people of color. Darwin argued that while all races had a common origin, they were not all equal. People of color were said to lack the capacity to improve their economic standing. Darwin's theory incited notions of social engineering to maintain the position of people of color as subordinates. Social engineering led to the Eugenics movement - brandishing deficit ideologies to rationalize actions to sustain the purity of the white race during the genetic pathology era of deficit thinking (Valencia, 2010). The racist discourse fueled by pseudoscience yielded a deep- 
rooted deficit ideology that has bled into modern discussions of education and school failure for low-SES, underserved and minoritized students. Currently deficit ideologies are perpetuated in discussions of the absence of social and cultural capital among low-SES communities and in communities of color.

\section{Social Capital}

Social and cultural capital are often conflated in education research. Both are used to forge deficit ideologies that place blame for educational inequities, such as opportunities for college access, at the student level. I will draw distinctions between both theories as well as discuss how the use of each theory as used in college access research and practice, is predicated on deficit thinking. I begin with social capital. Social capital is comprised of social connections (Bourdieu, 1986). It is the possession of or the potential to access resources via a social network. Social capital identifies a collection of assets that serve to improve life outcomes (Farmer-Hinton and Adams, 2006). These assets are associated with the elite class and are assumed to be deficient in low-income and underserved communities. The white elite utilizes social capital to build networks of information and secure position in the upper echelon of society's class. The construction of networks on college campuses during the colonial period as noted by Vine (1976) is an example of social capital. Patton (2016) successfully reasons that the state of higher education during that same period was drenched in white supremacy and racism. Furthermore, in an examination of the roots of deficit theory during that same era, Menchaca (1997) highlights the calculated efforts to prove that whites were superior, and people of color were not only inferior but subhuman. It is evident that African Americas have been historically excluded from the experiences and societal positions that are commodified in social capital theory. Without access to the experiences that are valued routes of accumulation, the social capital of African 
Americans is unrecognized. Social capital esteems the closed social networks operating under white privilege. African American social networks are viewed as worthless, forcing them to seek openings into spaces where there are opportunities to collect those assets that revered by standards of whiteness. School settings and settings such as college access programs become spaces to collect valued social capital in preparation for social mobility.

College access scholarship uses social capital as a lens to evidence that low-income and minoritized students lack access to personal networks that are rich with college knowledge (Conley, 2008) and access to resources for college planning as a barrier (Farmer-Hinton, 2008; Perna \& Titus, 2005; Reid \& Moore, 2010). Moreover, college access research supports claims that this social capital is required for college readiness to ensure social adaption and upward mobility (Corwin et al., 2005; Farmer-Hinton, 2008; Perna \& Titus, 2005). These assumptions reify college access ideology in asserting a need to provide connections that expand the social networks of participants. This assertion is problematic and reflects deficit thinking. The social capital of the dominating culture is valued more greatly than the students' social capital. Information on college going is important to first-generation students. While students may be the first in their families to attend college, it cannot be assumed that they lack social capital. They may have a social network within their church or community that offers support in the college going process (Yosso, 2005). The social capital that has been used in navigating racist systems sans college education is also notable. This navigational capital is accumulated as persons of color learn to maneuver through racially hostile environments such as college campuses (Yosso, 2005). 


\section{Cultural Capital}

I previously asserted that social capital and cultural capital are conflated in college access research. Cultural capital, like social capital theory stems from the work of Bourdieu. WinkleWagner (2010) found that the definitions and interpretations of cultural capital used in educational research are inconsistent, and thus may have muddled the meaning of the concept. Definitions of cultural capital cite critical components such as educational resources, skills, intellect, mannerisms, knowledge about educational institutions and educational credentials (Banks, 2009; Winkle-Wagner, 2010). Bourdieu (1986) established that cultural capital is passed from generation to generation and contributes to the reproduction of social inequality. Bourdieu's discussion of cultural capital does not make a distinction between race, class and gender, but rather uses “class” to include race and gender categories (Winkle-Wagner, 2010, p. 97). However, Winkle Wagner declares that Bourdieu was primarily focused on socioeconomic status.

This intermingling of race, class and gender concepts is reminiscent of the interchangeable language used to note poverty and lack of opportunity in the previous discussion on of the War on Poverty era. Additionally, race and class are often weighted equally in the access discourse. Race is a separate and systemic problem that cannot be circumvented via acculturation to the dominating class. There are clear issues with using cultural capital theory to frame the discussion of social mobility for African Americans. The issues of oppression associated with race cannot be overcome by amassing the skills, knowledges and credentials that comprise cultural capital. The oppression of African Americans cannot be relegated to a lack of cultural assets. This postulation denotes victim blaming and deficit thinking (Valenica, 1997, 2010). 
The college access research landscape uses cultural capital as a prominent theoretical lens to discuss removing access barriers (Banks, 2009; Corwin et al., 2005). Researchers assert that the acquisition of cultural capital is an underpinning determinant of underserved students' ability to succeed in college. This line of thought assumes that the habitus of the dominating culture is valuable, and those of other cultures are deficient. Winkle-Wagner asserts:

Although education does facilitate the acquisition of some cultural capital, those students who early acquired forms of cultural capital valued by the dominant groups will be more highly rewarded. They are also situated in schools or colleges to generate even more of the valued cultural capital. (p. 18)

It is the lifestyle of privileged students that begets and perpetuates hegemonic cultural assets. College access research uses the benefits that serve privilege to validate the need to assist students in gaining cultural capital. College access programs cannot reproduce a lifestyle of privilege by merely emulating cultural experiences. Moreover, students from underserved backgrounds do in fact have rich cultures that are valuable in actualizing their college aspirations. It is not necessary to subscribe to the standards of the elite. It is necessary to examine how embracing the culture of individual participants can serve to further the preparation agenda of college access programs as related to student identity.

\section{Cultural Wealth}

In challenging the cultural capital discourse, Yosso (2005) asserted a community cultural wealth theory, presenting a theoretical perspective that embraces the value of the cultures of historically marginalized groups. Community cultural wealth considers the collective forms of capital that marginalized groups possess. For African American students, cultural wealth is rich 
with experiences and habitus stemming from historical positioning and survival skills cum learned behaviors.

College access scholarship has noted the value of embracing the culture of the students served (Corwin, Colyar \& Tierney, 2005) however the discourse has not called out postsecondary institutions in their negligence of valuing the cultures of a diverse student body. Cultural wealth (Villapando and Solorzano, 2005) focuses on meeting the needs of the individual rather than implementing a standardized model of programming that may not be suitable to the diverse needs of students. Rather than assuming that there are gaps to fill, the focus is on embracing the students' culture as a valuable resource for college access programs. In the case of family support, many programs operate under the notion that the parents and families of underserved students do not value education and necessitate information that will educate them on the importance of the benefits of postsecondary education. In opposition, cultural wealth welcomes the families; cultures and validate the experiences and expectations of said cultures. Yosso (2005) cites familial culture as an important component of cultural capital.

\section{College Access Students}

\section{African American Students}

It is evident that higher education culture and policies were well established long before the first African American student was enrolled. The first U.S. institution of higher education was established in 1636 (Cohen \& Kisker, 2010), yet no African Americans graduated college before 1828 (Woodson, 1998). Woodson (1998) outlines the history of African Americans in higher education, beginning with the efforts to establish institutions of higher education for Blacks in an effort to open their eyes to the injustice of American society and resultantly incite emigration to Liberia. The efforts were suborned by colonizationists and opposed by 
abolitionists. Institutions of higher learning for Blacks began to sprout up in response to not only ulterior motives to educate Blacks, but also the refusal of preexisting institutions to enroll Blacks. In one incident, a Black student was accepted only after swearing that he had not one drop of "Negro blood." As Blacks began to be accepted by colleges and universities, resultantly professors resigned, and white students dropped out. Harper, Patton and Wooden (2009) relay a historical analysis of policies that have affected African Americans access to higher education, beginning in the 1820s. The historical exclusion of African Americans from educational opportunities has contributed to what Ladson-Billings (2006) terms the education debt. The education debt describes the societal liability for the recurrent inequity of resources available for African American students. Comprised of historical, economic, sociopolitical and moral factors, the education debt creates an education deficit, categorized by disparate educational outcomes. Poorly funded schools and inadequate resources underwrite these outcomes.

The knowledges and experiences that are held as prerequisites for and valued within the college culture have not been readily available for African American students. Formal schooling presents as a route to accessing these knowledges that are associated with the dominating culture (Yosso, 2005). However, formal schooling for minoritized groups is hampered by limited resources. College access research affirms a notable variance in the quality of schooling across the social strata (Corwin et al., 2005). Lack of resources and underfunded schools reflect the continued racist subordination of Blacks in the educational system (Harper, Paton \& Wooden, 2009).

The history of opposition to African Americans' enrollment in higher education, confirms the perennial struggle for access. Efforts to overcome the barriers propagated by racist practices in college admissions have necessitated laws and policies to mandate inclusion for African 
Americans in education. The inequities that historical exclusion beget, are challenged and demystified by the use of CRT as a theoretical framework. CRT scholars illuminate the causal relationship between structural racism and white supremacist ideologies and the negative educational outcomes for African American students in accessing and completing higher education (Harper, Patton \& Wooden, 2009; Patton, 2016). The culturally different identifier that Yosso (2005) stated is used to codify race, is used in education research to group together those who have been oppressed by racism, social stratification and economic disadvantage. Such are the terms used to label students in need of college access assistance.

\section{First-Generation Students}

For many first-generation college students, the heterodoxic cultural knowledge of college and admissions processes, passed down from college educated parents, is unavailable (Carter, 2005; Reid \& Moore, 2008; Corwin et al., 2005). Attending schools that fail to obviate the educational debt (Ladson-Billings, 2006) inhibits access to highly qualified teachers, well trained school counselors, advanced technology and rigorous curricula. These things are among the noted essentials required for college readiness (Conley, 2008; Bergerson, 2009; Welton \& Martinez, 2014). This disconnect from dominating cultural knowledge and social experiences can serve to overshadow the efficacy of the cultural wealth (Villalpando \& Solorzano, 2005) that these students possess. Embracing cultural wealth is important to students' identity as well as establishing students' access to postsecondary pathways. It is time to shift the focus from what underserved students lack to highlighting what they bring with them on the pathway to college, and how their individual agency has been aided by their cultural knowledge and experiences.

The challenge of serving first generation college students through college access programs begins with unpacking the researched based and widely accepted perceptions of their first- 
generation status. Studies assert, first generation students require peer support to overcome intellectual and cultural difficulties (Dennis, Phinney, \& Chuateco, 2005); first generation students are at a distinct structural disadvantage when it comes to family income and support, academic preparation, and educational degree expectations and plans (Pascarella, Pierson, Wolniak \& Terenzini, 2004; Reid \& Moore, 2008). True enough, first generation college students encounter many obstacles as they enter into postsecondary institutions. However, research focusing on how these students can change in order to adapt to college, ignore the exclusivity that postsecondary institutions were founded on, and the discrimination that has sustained it. Patton (2016) discusses the racist beginnings of higher education, and the foundations of white supremacy and racism that continue to permeate the admissions practices, curriculum and campus culture. Research advocating student level interventions to traverse institutional racism fails to prepare students for the harsh realities of entering a space where they will be marginalized and discriminated against. Rather than illuminating the realities of marginalization on college campuses for underserved students, college access scholarship resorts to victim blaming and doling out strategies to resolve internal limitations of students.

It is useful to examine the ways in which college access research hones in on student level problems as they demonstrate a reverence for higher education institutions. The following studies reveal the academic stance on this point:

Pascarella, Pierson, Wolniak \& Terenzini (2004) expound on the college experience of firstgeneration college students, and benefits to attending college. Findings reveal that level of postsecondary education of the parents of first-generation students has an influence on the students' selectivity of the institution of enrollment, nature of college experiences, and cognitive and noncognitive college outcomes. Additionally, there was a marked difference between the 
first-generation students and the comparison groups in the influence of college experience on the outcomes of college.

Reid and Moore (2008) investigated the experiences and perceptions of first-generation college students on their secondary preparation for postsecondary education. The authors assert that most participants were academically successful in high school. Reid and Moore (2008) assert that as a means of assisting students from underserved populations, “...it is important that educators... understand the barriers to accessing a postsecondary education and put into place interventions that prepare all students for higher education throughout the K-12 educational process (p. 214).” Using a social capital theory lens to interpret the data, the study found two overarching themes: ”...(a) preparation which helped with college success and (b) skills lacking for college success (p. 245).” All participants reported that relationships with teachers and staff at the secondary level helped prepare them for college. Thus, the authors put forth several recommendations for school staff, including teachers, administrators, and counselors. In their valuation, teachers are key in motivating and encouraging students to go to college and should have high expectations for students; and administrators must ensure access to rigorous coursework as well as adequate equipment and supplies in the classroom. Furthermore, it is asserted that school staff should provide opportunities to educate parents of first-generation students on the necessity of challenging coursework. This study concludes that in order to promote success for first-generation students, the family and school must work together to provide support, and advocates a curriculum alignment between K-12 and postsecondary systems.

Ishitani (2006) addresses the issue of low college retention rates among first-generation students, and investigates the longitudinal persistence behavior of first-generation students and 
their graduation rates, attending respective four-year institutions. The study reveals that students who attend selective or moderately selective institutions are more likely to graduate within four

years. Being a first-generation student reduces the odds of graduating within 4 and 5 years. Yet, variables such as continuous enrollment and high school academic intensity positively affected graduation timing.

The preceding studies highlight student deficiencies necessitating student level strategies to offset the effects of being first-generation. Many of the proposed tactics are hampered by school failure. Access to informed counselors and rigorous curricula is often unattainable for these students due to the opportunity gap. The students that are served are the core of college access research and programming. Centering the discourse on student weaknesses steers strategies to rectify access barriers off course. Themes to improve access via readiness are wrought with an emphasis on hegemony and whiteness.

\section{College Access and Whiteness}

College readiness has been defined as the level of preparation a student needs to access and succeed in college (Conley, 2008). Meeting the objectives of readiness for marginalized students, college access programs aim to create and bolster college readiness by providing academic and college admissions assistance. The necessitation of efforts to increase access and college success for African American students is evidenced by the disparate rates of college enrollment. However, the pathways and pipelines of college access delineate a one size fits all approach dictated by the dominating culture. I contend that the themes of college access and readiness function to promote hegemonic cultural knowledge related to college attendance, with an assumption of "whiteness as the norm” (Guess, 2006, p. 650). 
Researchers on access detail tactics to support and improve the college readiness of underserved students (Bergerson, 2009; Conley, 2008; Corwin et al., 2005; Reid \& Moore, 2010). Suggestions of supplemental assistance are often centered in whiteness. In a discussion of whiteness theories, Thompson (2001) states that privileges such as access to good education are associated with material whiteness, connected with systemic racism. The valuation of privileged knowledge and experiences in college access reflects material whiteness. By extension, the components of readiness upheld by research, including academic preparation, acculturation and supplemental social support, advance notion of whiteness as the ideal. Exploration of these components is laced throughout the access discourse and present as themes of effective college pathways. Next, I will explore how these themes are employed in college access research.

\section{Academic Preparation}

Research notes high academic achievement as one of the primary keys to college access (Cabrera \& La Nasa, 2001; Perna, 2005; Corwin, Colyar \& Tierney 2005). Thus, academic preparation is seen as a critical component of college preparation programs (Begerson, 2009; Perna, 2005). However there is limited acknowledgement of the detrimental systemic racism that impedes academic achievement for African American students in research on access. Remarks on the disadvantages and barriers affecting educational outcomes are framed as students' deficits in social and cultural capital. Racism is not identified as a contributing factor. Instead, the salient antidote to meeting college level academic qualifications is rigorous college preparatory curriculum (Cabrera \& La Nasa, 2001; Perna, 2005; Perna \& Kurban, 2013). This solution is flawed given that "the mainstream achievement ideology requires individuals to take ownership of their successes and failures, and it fails to account for structural conditions that 
might constrain or even impede students’ abilities to achieve their maximum potentials in school and life (Carter, 2008, p. 467).”

Perna (2005) conducted an analysis of literature focused on the academic preparation and college access of low-income and "other disadvantaged groups”, defining academic preparation as the quantity and quality of courses. Notable findings of this analysis point to attending less affluent schools, less academic climate and tracking as limitations. Admitting that students who have been historically marginalized are those who are least likely to be academically prepared, Perna suggests that college preparation programs supplement school level failures with a rigorous supplemental academic curriculum. The fact that the availability of rigorous academic preparation is disparately unavailable to low-income and underserved students amounts to racism by consequences (Guess, 2006).

The reverence of high academic achievement in college admissions is connected to whiteness and privilege. Retrospectively, the early admissions practices of American colleges, students were required to know Latin and Greek, and later an added requirement of arithmetic (Cohen \& Kisker, 2010). Students were subjected to oral examinations and were at times exempt from admissions requirements due to the need of the college to fill the roll. Students who matriculated into colonial colleges were from families whose wealth could afford higher education, and were prepared for specialized occupations in ministry, medicine and law. Options for college training was predicated on wealth and elite privilege during an era when blacks were considered inherently inferior and ineducable (Menchaca, 1997). Hence, the construction of the college culture and admissions requirements were realized in a racialized space with no influence or consideration of diversity. A record of high academic achievement and resultant inferred 
aptitude, as a precursor to college admissions was constructed over time via the curriculum. Patton (2016) articulates the racialized components of the college curriculum:

The curriculum operates with a disposition toward "cannon" knowledge and information that has been passed down throughout generations, ensuring whiteness remains embedded, regardless of subject matter. Given its normalcy, the curriculum is rarely questioned because it provides a "good" education without accounting for the benefits that accrue for white people. (p. 320)

Arguing that college access programs act to counteract school failure and increase college reenrollment and degree attainment with rigorous supplemental academics sustains a college ideology centered on whiteness. While academic ability is certainly a contributing factor to degree persistence among African American students, there are issues beyond the classroom that must be acknowledged and addressed when examining the degree attainment rates of minority students.

Academic preparation alone is not a clear determinant of college access. Hatt (2012) declares that smartness is a social construct operating as symbolic capital. Students who exhibit behaviors that teachers associate with smartness, are those who follow the rules and meet the expectations of authority figures. As an example, in college access there exists a hidden curriculum of readiness that coincides with academic preparation. In addition to the rigorous academic expectations, there are issues related to cultural adaption once in college life. College campuses are rife with racialized policies and practices that are unwelcoming to African Americans (Patton, 2016). Students are expected to learn how to take on the role of college student (Collier \& Morgan, 2008). This expectation aligns with Hatt’s (2012) discussion of 
smartness as students are expected to exhibit behaviors that are valued by those in authority, e.g. professors, advisors and other college staff.

\section{Acculturation}

My previous discussion on cultural capital examined the role of culture and theory in college access. Culture is operationalized as a theme of college access via cultural exposure. Studies conducted on college access programs cite exposure to college campuses (Bergin, Cooks, \& Bergin, 2007) as means to increase opportunities for access. In their review of the role of culture, in college access Villapando \& Solorzano (2005) note the use of cultural experiences, in access programming, such as field trips to provide cultural exposure. These activities serve as an intervention to expose underserved students to activities that are common place for affluent students (Hagedorn \& Fogel, 2002). Engaging students in cultural exposure activities is demonstrative of the assumption that the values of the dominating culture are most conducive to academic achievement. College access research that argues for acculturation via exposure elevates values associated with whiteness.

Corwin et al. (2005) term the process of disseminating information regarding the resources and knowledge that are required to matriculate and succeed in postsecondary education as intellectual scaffolding and cultural scaffolding. Intellectual scaffolding includes academic preparation, college selection and admissions information, financial aid assistance and individual aspirations. Cultural scaffolding is described as the framing of the intellectual scaffolding concepts within the sociocultural background of the individual student. The scaffolding processes acknowledge student culture, but also intimate that their culture is not valuable enough to effectively forge college success without aid. 
Bergin, Cooks, and Bergin (2007) noted that a key point of the EXCEL college access program is to maximize cultural and social capital of participants as means of affording them cultural advantages that promote social mobility. The participants were minorities, and predominantly African American and Latino. The authors state that cultural capital gained via exposure to college campuses is often limited to affluent and nonminority youth. Presenting the experiences of affluent nonminority youth as models to signify cultural capital endorses whiteness as the standard for what counts as culture. Additionally, connecting maximized cultural advantages with opportunities for social mobility supports the untruth that there exists a level of social equality that makes it possible for “... any Black person who works hard to achieve economic self-sufficiency (hooks, 1994, p. 29).”

College access research suggests that the ability to successfully navigate the postsecondary system requires access and accumulation of specified cultural knowledge, or whiteness, that translates into the skills and strategies that support degree attainment. Collier and Morgan (2008) purport that students who arrive at college with a mastery of the student role possess an important resource of knowing what their professors expect of them as well as how to meet those expectations. It is apparent that professors penalize underserved students as a result of expectations derived from their hegemonic perceptions. There is no definitive process of how and where the "student role" is learned. Yet there is a "common sense" assumption (Menchaca, 1997) that there is a singular student role that is necessary to succeed.

\section{Support Networks}

Social support networks are regarded as conduits for information related to college access for underserved students. Parents, peers and counselors comprise the social network in college access research (Farmer-Hinton \& Adams, 2006; Holland, 2011; Perna \& Titus, 2005; 
Villapando \& Solorzano, 2005). The research on the contribution of support networks for underserved students is valuable in promoting the social capital available to underserved students. However, this research follows the path of the prevailing college access ideology in highlighting deficits within these networks.

There is deficit constructed assumption that underserved students and their parents do not value education (Villapando \& Solorzano, 2005). Perna and Titus (2005) examine parental involvement in college access, conceding that measurements of parental involvement are based on traditional white values. Viewing parents as deficient sources of college going support is a problematic ideal of college access research. Parents of underserved students are valuable assets to the social network of college access students, yet their contributions are often dismissed as inadequate within the popular cultural framework of the college access ideology. Yosso (2005) points to familial capital, “cultural knowledges nurtured among familia (kin (p. 79),” as being additive to the sense of connection to community and it resources. This community provides lessons on coping and caring that supports marginalized students sense of belonging. This sense of belonging is valuable for students as they enter higher education institutions where they are seen as outsiders needing to adapt.

Peers serve as additional members of the social support network. Holland (2011) found that African American students relied on peer influences in attaining information about college and developing educational aspirations. Holland commends the encouragement that peers provide, but cautions that peers may be a limited source of information and asserts that parents and families need to become more knowledgeable in college preparation processes.

Farmer-Hinton and Adams (2006) examine the role of school counselors in preparing college-bound Black students. They found that availability of the students' high school guidance 
counselor sustains a familiar relationship to assist students in navigating the cultural landscape of college. While providing academic guidance and social support, counselors become a network of adults who helped students overcome social and cultural limitations. These assertions ignore the cultural capital that these students hold. In addition, many students in need of college access assistance attend schools that lack a sufficient number of counselors to serve their students' needs.

\section{Conclusion}

College access research serves to review and recommend best practices, as well as inform policy, in the absence of a normalized model for college access program implementation. Examinations of the components of college access programs often take place with no accounting for structural issues within the education system that affect the opportunity gap for low-income and minoritized students. Research based findings and recommendations fall short by attributing the predominance of access barriers to students’ lack of academic preparation, insufficient social support, ignorance of college culture and inability to process information regarding admissions and financial aid. This reflects the inherent themes of a deficit based college access ideology. These themes are recurrent in literature and lack a critical stance on the root causes of school failure. The identification of themes of access barriers is beneficial to increasing college access,

however the focusing on student level strategies advances the myth of meritocracy (Patton, 2016) and offers thwarted solutions. Underserved students' experiences in communities that have been structurally denied quality resources automatically disqualify them for readiness, unless they submit to assimilation and acculturation to standards of whiteness.

Enberg and Wolniak (2010) suggest that cultivating college access requires the inclusion of both students and organizational structures as key preliminary elements. Directors of college 
access programs play a key role in the organizational structure. The historical underpinnings of college access involved a prescriptive model with a focus on blaming the victim. This deficit thinking has continued to impact how college access programs are implemented. To prevent the perpetuation of such deficit model approaches it is necessary to identify ways in which program directors develop and implement college access mission and goals. The research and resultant theories focused on college access abound with best practices and models of implementation. This study answers the question, to what end? Given that theory informs practice, it is certainly true that the ideologies of the persons in leadership serve to guide the program. This study will fill a gap in the current college access literature by addressing the assumptions and ideologies that impact how directors of college access programs develop and implement programming. 


\section{CHAPTER III: METHODLOGY}

\section{Introduction}

Theory and literature on college access uniformly identify key factors that aid in supporting college readiness for African American students: academic preparation, financial assistance, mentoring and a support network. Despite a multitude of college access research and practice predicated on these factors, degree attainment for Africans Americans remains low. According to National Center for Educational Statistics data, 22\% of the African American population attain bachelor's degrees, while, disproportionately, $41 \%$ of their white counterparts earn degrees (2012). Thus, it becomes necessary to further the understanding of factors that lead to college enrollment and degree attainment for African Americans. This qualitative study examines the perspectives of college access programs directors on essential programmatic thrusts in meeting access goals and objectives. Data was collected via semi-structured interviews, field observations and document analysis. Using critical race theory (CRT) as a framework, I chose an ethnomethodological approach to address the research questions that guided this study. The use of qualitative research methods was most befitting in conducting a critical ethnomethodological study exploring program directors’ perspectives on carrying out the objectives of college access programs within the context of program operations.

\section{Purpose of the Study}

The purpose of this study is to identify how the assumptions of college access program leaders affect their common practices and program implementation in serving the needs of African American students. In addition, the tensions that exist among theory, research and practice in the college access field are examined. 


\section{Research Questions}

The following research questions were used to guide this study:

1. What are the underlying assumptions that college access administrators have about the African American students that they serve? How do these assumptions play out in the actual practices of the program services?

2. How do the explicit goals of college access programs align and/or contradict with the actual practices of the programs?

I utilized these research questions to guide my study. I sought participants whose employment status equivocated as administrators or leaders of a college access program. Potential participants were contacted via electronic mail and signed consent forms upon agreeing to participate in the study. Each participant was interviewed in a location of their choice to ensure privacy. The interviews were audiotaped and transcribed by the researcher. Further data were collected during observations of the participants during their work day as they went about the routine activities of their jobs, and via document collection of job related artifacts.

\section{Qualitative Techniques}

Merriam (2009) states that applied research is a systematic process to gain more knowledge of and improve the quality of practice within a specific discipline. Qualitative research focuses on how people construct their everyday lives and experiences. She notes that critical research looks beyond how people see their worlds and seeks to bring about change through inquiries that focus on power and how it is negotiated. This study uses a critical ethnomethodological approach in exploring the perceptions of college access program directors' on how to best serve African American students on the pathway to college. Ethnomethodology is defined by Garfinkel (1967) as “...the investigation of rational properties of indexical 
expressions and other practical actions as contingent ongoing accomplishments of organized artful practices of everyday life (p.11)”. Ethnomethodology was utilized due to my focus on studying persons within the context of their experiences. Garfinkel (1967) relates that this form of inquiry examines common practices and shared practical knowledge of members of a group or organization. The members of the group in this study are college access program administrators. My objective to explore how college access program directors' assumptions of students' needs drive their work, undergirded my use of ethnomethodology. While ethnography is often used in qualitative research to explore individual experiences and stories (Crotty, 1998; Merriam, 2009), I found ethnomethodology to be more suitable for the purpose of this study in exploring the context of shared beliefs and common practices among college access program leaders.

During this study, I conducted five interviews, one with each of the five participants. Each participant served in a leadership role of a program that has college access as an objective at the time of data collection for this study. The five program directors, Jay, Peter, Mark, Sam and Rochelle, will be introduced with descriptive details in chapter four of this dissertation. During the interviews, I gathered information about how program directors approach their work in planning and implementing college access programs. Interviews reveal data that cannot be observed, as well as to gain information about past events that cannot be replicated. (Merriam, 2009). The use of interviews to collect data was beneficial in obtaining insight into the intangible factors that inform how and why program directors design program activities. Additional data was collected using field observations and document analysis. In the field, I observed each participant at their respective program sites during a routine work day. The artifacts used for document analysis included resumes, program brochures, program schedules, annual reports, organizational charts, web sites and program handbooks. 


\section{Data Collection}

I conducted five interviews with participants who were employed as directors of college community based, federal and university based access programs. I utilized a semi-structured interview process purposed to guide the participants in reflectively relating their perceptions and experiences. Semi-structured interviews are guided by a list of flexibly used questions while yielding specific data from each participant (Merriam, 2009). My use of semi-structured interviews allowed the participants to openly communicate their perceptions about their experiences leading college access programs with limited guidance by the list of interview questions combined with probing by the researcher. I developed interview questions following the recommendations posited by Dilley (2000) as well as Dana, Dana, Kelsay, Thomas, and Tiipins (1992). I developed research questions based on my insider knowledge of college access programming as well as the current literature on college access programs. This list of interview questions served to guide my participants down the road that I wanted them to take (Dilley, 2000). I often utilized probing techniques during the interviews to encourage the participants to elaborate on the de details of the experiences that they shared, as well as to clarify my understanding of the experiences as they were relayed to me. Often participants were prompted by one question to begin a free flow of thought that answered questions that followed on the interview protocol. When seeking clarification, I used reflective statements (Dana, Dana, Kelsay, Thomas, \& Tiipins, 1992) as probes to assure the participants that I was actively listening. At the end of each interview I asked the participants to share their resumes and made a request for program documents. Three of the five participants sent me a copy of their resumes. All five participants gave me some form of documentation or artifact related to their program operations. 
I conducted field observations of each participant. Observations allowed me to observe first hand things that have become routine to the participant that may not be reported during an interview (Merriam, 2009). I used field observations to observe the participants engaging in the everyday routines in their roles. I observed both their administrative and programming environments. I observed staff meetings, staff interviews, programming and routine activities of the day to day world of the program directors. I found myself having to remind a participant that my study was focused on college access directors, rather than students. There were times when I was steered towards observing program activities where the director would not be present. I found this curious since my recruitment materials stated that I was studying the administrator role in college access. Peter originally scheduled my observation at the summer academic program at an offsite location, and I realized that he would not be there when I called to confirm my appointment. Jay directed me to follow her students to class, after she completed an opening meeting and group presentation. Both times, there was an awkward moment of confusion as I explained that I wanted to observe them personally. Sam only offered observation times where I would see students, avoiding scheduling on days that he had no student contact. During observations, I took descriptive notes to obtain knowledge of the context of the college access program directors' routine activities. As I conducted field observations, I was at times a participant observer as participants turned to me to offer details regarding the events that I was observing. These interactions at times turned to discussions about the program goals and the participants' thoughts on the development of the event being observed.

\section{Recruitment}

The participants of this study were chosen based on their professional role as directors of college access programs. To meet this criterion, they had to be managerial administrators of 
programs that included preparing students for college as part of the program mission. The sampling methods for this study were both purposeful and snowball sampling. Purposeful sampling involves choosing a sample based on the participants' abilities to offer the most information about the central purpose of the study (Merriam, 2009). I began recruiting participants who are employed as administrators of college access programs that I am familiar with due to my career in the field of college access. I also widened the potential pool by contacting area college access programs found in the National College Access Program Directory (http://www.collegeaccess.org/accessprogramdirectory/search.aspx). I sent out a recruitment email (Appendix B), contacting over 60 programs, and rendered a response from three program directors. My final sample was further assisted by two of the participants, in this study, through snowball sampling (Merriam, 2009). They referred colleagues to the study. The referrals yielded three more willing participants. One agreed to participate but canceled the interview and never rescheduled after being contacted to do so. Another was located in another state and thus ineligible for the study based on the region of the study's focus. The last willing referral is a participant in this study.

\section{Statement of Positionality}

My interest in college access programs is very personal. I am myself a first-generation college graduate. I have also served as a director of a college access program for eighteen months. In addition to my work in college access, I have experience as an academic advisor at public, private and for-profit postsecondary institutions. Looking back, I must say that my career goals were fueled by my own experience navigating the path towards earning a college degree. While I was never involved in a college access program per se, I did attend a Chicago Public Schools high school program, from $7^{\text {th }}-12^{\text {th }}$ grade, that had a college prep curriculum. College 
was understood as our next step, although it was not specifically talked about often. There were no college banners hanging in hallways or college tours. However, we had more rigorous academics than other students enrolled in our same grade.

My mother was adamant that I was going to college. Period. No other option. Yet, she did not have the personal knowledge to advise me about college. Most of my discussions about college life and expectations took place with the parents of my high school classmates. However, my concepts of college culture were taken from pop culture, specifically the movie School Daze and the television program Different World. Given my pop culture influenced lens, when my older sister, enrolled in a nearby college and moved into the dorms, I thought she was in for the time of her life. She did, in fact, have a robust social life. However, after her year away, I learned lessons about academic probation, high-cost tuition, and credit card debt. This led to me entering college with a focus on maintaining a strong GPA.

Following my time as an undergraduate, I began to reflect on how I learned to navigate college. I realized that having on-campus employment in university departments offered some insider knowledge into campus policies/politics. I learned as I went. Succeeding in college took more than scholastic aptitude. I had to learn the culture. I recall the campus Office of Minority Student Affairs orientation where I was stumped by the concept of a credit hour. I was quite simply green about college. My mother sent me off with a mere expectation that I return with a degree, she had limited insight into the actual college experience. It was while working at an oncampus job, that I gained insight into the college culture. I decided that I needed to be involved in activities and networking that would serve to leverage my post-college trajectory. As a result, I volunteered, took practicum courses and applied for internships. While I managed to figure it out, it always bothered me that I was never formally prepared to seek these opportunities. I felt 
that my college prep curriculum left me at the gate of the ivory towers to fend for myself. I eagerly shared each lesson and tip learned with my African American classmates figuring that if I did not know then they did not either. In a since, I have always been about the business of ensuring college success for African Americans. After college, I worked briefly in social services and for some time as an academic advisor. However, I have had a consistent interest in college access and degree attainment of African Americans.

I worked for nearly two years as a director of a program that was primarily focused on college access. The participants were all African-American and identified as low-income. The program provided ACT prep, mentoring, college tours and field trips to students in the $10^{\text {th }}-12^{\text {th }}$ grade.

My research is beset by my personal frustrations with the college access field and my opinions on how the individualized needs of students can be overshadowed by meeting the terms of funders and agency policies. Throughout this research study, I sought to look deeper than student outcomes, and enrollment and graduation rates. I set out to unveil the particulars of how college access programs serve students’ needs. While many research questions in this area have been asked, answered, and analyzed, I endeavored to explore the experiences and motivation of program directors that lend to the shaping of college access programming.

\section{Data Analysis}

I used my sociological imagination (Denzin, 2002) as a tool to think critically, historically and biographically about the data that I collected. As Denzin (2002) notes, I sought to give meaning to how the experiences of directing a college access program are perceived and constructed by program directors. After the interview data had been collected, the transcripts were transcribed verbatim; I then analyzed and coded the data to reveal themes and subthemes. 
Once the interviews were transcribed, an open coding analysis was conducted (Merriam, 2009). This organization of the data through coding (Merriam, 2009) allowed me to infer themes and subthemes across the data.

Initially. I read through the transcripts and made notes using the data to deduct subthemes related to my research questions. I used my research questions and the critical race theory framework to generate the most prevalent themes across the data. I then created data tables sorting data according to interview questions. In doing this, I categorized the data by grouping concepts that pertain to the same phenomena (Strauss \& Corbin, 1998). I utilized open coding as I went through the data and assigned similar phenomena the same name. The concepts were based on the tenets of critical race theory. These tenets were mined from critical race theorists who have researched and applied critical race theory as a theoretical framework for educational researchers (Delgado \& Stefancic, 2012; Ladson-Billings,1999; Yosso, 2005). As Strauss and Corbin (1998) suggest, the names of the categories assigned during analysis, formed from the pool of concepts known to me as a result of my knowledge of the tenets of critical race theory. This process assisted me in identifying the commonalities as well as any unique components of the themes across the experiences of the participants. I also performed an analysis of the documents provided by my participants. The documents that used were produced prior to my research study and were” thus nonreactive and grounded in the context under study (Merriam, 2009, p. 163).” I conducted a content analysis (Merriam, 2009) to determine how the documents related to my research questions.

\section{Trustworthiness}

Validity is not an attribute of a particular research method, but rather it relates to the accounts of the data and subsequent conclusions reached for a particular purpose (Maxwell, 
2002). I used triangulation to enhance the validity of my research findings (Mathison, 1988).

The three sources of data that I employed to achieve triangulation are interviews, observation and document analysis. Observation allowed to me to see how the participants' actions aligned with what they self-reported during the interviews. Furthermore, document analysis filled in the gaps of program policies and organizational administration. As I developed a relationship with my data and began the analysis process, I often engaged the thoughts and insight of my dissertation advisor as a way of balancing my analysis of the data. This was done to ensure that I was not allowing my personal bias to dictate the story revealed by the data.

\section{Conclusion}

I used qualitative data techniques to conduct an ethnomethodological study of how college access program leaders’ assumptions and perceptions affect their practices. I collected data via semi-structured interviews, field observations and document analysis. I interviewed five participants, with interviews ranging from 45 minutes to two hours. My observations took place in the programming settings as well as office spaces of the participants. After the interview I collected and analyzed documents including, mission statements, program marketing materials, schedules and annual reports, as well as three participants' resumes. Using a CRT as a framework, I coded the data and used the resultant themes to make sense of the data during data reduction. The data collectively revealed the story that I will share in chapters four and five. 


\section{CHAPTER IV: RESEARCH CONTEXT}

This study was conducted in a large city in the Midwest, during the early spring and over the summer of 2015. The city is home to many four-year institutions, and hosts a large community college system. In addition, there are a breadth of programs with college access as a part of their missions. The programs in the area are both university-based and community-based organizations. Among these programs is a host of federally funded access programs including Upward Bound, Talent Search, and Gear Up. This study focuses on five programs, one federal TRIO program - Rise, one university-based - Scholar Tank, and three community-based programs. Two of the programs also provide scholarships for students to attend private high school and/or elementary school - Beyond Ready and Young Achievers; and one program is a sports program, Catch.

\section{Participant Profiles}

\section{Sam}

Sam is Latino and serves as director of Scholar Tank, a university-based program for academically talented students, at a private selective enrollment institution. Sam's demeanor is warm, and he answered questions freely, giving rich details. He is the youngest of the participants and his disposition reflects a desire to please others. He had an agreeable nature and answered my questions in a soft and warm tone of voice. Sam is a first-generation college graduate who attributes his college enrollment to an informal mentor that he became acquainted with while participating in a community arts program. While attending private school, and earning grades that made him a good candidate for college, his counselor advised him to enroll in military school or community college, without having looked at his transcripts. Sam entered the world of college access after serving as an admissions advisor at a selective enrollment 
university. He was drawn to college access as a result of interacting with students who were not eligible for admissions and his concern about students’ lack of access to information early in their high school careers. As an admissions officer, he met the Scholar Tank team and was impressed by their students and the work that the program did to prepare students. When there was an opening for the associate director, he applied and subsequently joined the team. When the director resigned, he became the interim director, and at the time of our interview had been officially appointed as director.

My interview with Sam was held in his office. Sam’s office has a large L-shaped desk and a round table where we met. His office windows overlook the busy street at the front of the building. Sam's office is located directly next door to the other college access program office. There is additional Scholar Tank program office space down the hall from Sam's office, where the associate director and volunteer staff (comprised of parents, university students, and Scholar Tank alumni) are housed. This office has two cubicles as well as an open work space. There is also an open area directly outside the program office, with chairs and tables that can be arranged according to need, that is used for large meetings of the students. The Scholar Tank offices are housed in a suite that also contains another university based, college access program, that is, in fact, a federally funded TRIO program. However, at the time of our interview, Scholar Tank was preparing for a move to new office space, across campus.

Scholar Tank operates under the civic engagement umbrella of the University and is currently funded solely by the university. The program provides academic and social enrichment to high-achieving students, with limited resources, attending public high schools in the city, while preparing students to enroll in selective colleges and universities. Students apply for the program in their freshman year of high school, and once selected begin participation in the 
summer prior to their sophomore year. Over the course of the three-year program, students attend classes on the sponsoring campus, and attend cultural events, throughout the calendar year. The program year is broken into quarters. Students choose classes from a schedule each quarter and are required to complete a specified number of program credit requirements, each year, that are tracked via a transcript.

\section{Peter}

Peter is African American, and is the Educational Programs Director for Beyond Ready, a community-based college access and high school scholarship program. His office is in a building dedicated to Beyond Ready. The building houses staff offices, a kitchen, a small auditorium, a conference room and computer lab. Peter is a first-generation college graduate who had personal experience with involvement in college access programming while he was in high school. Peter is a young man with a wise soul. He is thoughtful as he answers the interview questions, and shifts between relating professional facts and knowledge, and passionate recollections of personal experiences and perceptions. He had a career in college admissions, and after encountering students who he felt were motivated, but uninformed and unprepared for the institution where he was an admissions officer, he was spurred to address the disconnect. He relayed his frustration with attempting to recruit students who might have been college ready if only they had the necessary information, as the primary impetus for his work in college access, These were kids who were falling into line, but for whatever reason, I have my own thoughts about that, but for whatever reason, these students just didn't get that information. And now instead of them saying these are the schools that I want to go to, and these are the reasons why. Or this is the best fit for me, it's like this is the only school 
I can get in or this is the only school I can afford. So, here's where I'm gonna go. And that's not what you want your college experience to be (Peter Jones interview).

At Beyond Ready, all students attend private tuition based schools and are paired with mentors. The participants are 100\% African American. The mentors partially fund the tuition for participants”' attendance at private high schools. The office contains a computer lab, conference room, auditorium, kitchen in addition to staff offices. College banners hang from the ceiling in the entry area where the reception desk and waiting area are located.

\section{Rochelle}

Rochelle is African American and the director of the Young Achievers high school program. She has been in this position for five years. Young Achievers is a community-based organization that supports low—income students from elementary school through college. Rochelle’s educational journey was peppered with personal challenges that instilled determination to go to college and finish. She relays stories of excelling in school (she participated in the International Baccalaureate program from $6^{\text {th }}-12^{\text {th }}$ grade) while her family faced homelessness and financial struggles. She speaks with a fast and clipped cadence as she talks openly and candidly about her struggles to earn a degree as well as her opinions about how college access programs are serving students. Rochelle attended a historically black university (HBCU) and earned a degree in Food Science. After graduating she worked at a market research firm and made a career change after her experience volunteering a nonprofit program connected with the church that she attended. She decided that she wanted to work with programs that helped students, with backgrounds like her own, to get into college. She has worked for a TRIO program, a small trade company that developed stem education programs to encourage underrepresented students to enter the STEM field and finally landed at Young Achievers, where 
she developed the high school program. Prior to her employment, the program had only served students during grades K-8.

Young Achievers serves a low socioeconomic population and provides educational support from kindergarten through college. The program provides mentorship, tutoring, scholarships and social service support for first-generation African American and Latino students and their families. The office space, located in a busy hub of the city, on the second floor, contains private offices, a reception and waiting area as well as conference room. The basement of the building is one of the locations used for tutoring space. The annual summer program is located within a private school also in the city’s downtown. Young Achievers recruits students while they are still in elementary school. The recruitment is done by word of mouth, and referrals from their partner schools.

\section{Jay}

Jay is African American, and the director of a community based Upward Bound (UB) TRIO program housed in Rise Community Center. Jay came to the field of college access by happenstance. While working on a graduate degree in the field of early childhood education, she took a part-time job working at a private high school with a strong college prep thrust. The parttime job became a full-time job at a public city high school, and when that ended she came to Rise as the UB director. She states that she prefers working with young learners in the classroom, but with high school students during out of school time,

I think I like working in out of time with high school students. I couldn't work with them in the classroom. That would make me crazy I think. I like really young learners. I think in a classroom setting, but out of school is really different from in school. You're not bound by the curriculum. You're really...we do have classrooms, and our teachers teach, 
but you know I'm trying to think more about the bigger picture. What experiences do we provide you to help you build your own social capital and competencies, so that you can be successful in college. And I really...I found that I really like that (Jay Morgan interview).

As the interview with Jay progressed, it became clear that her affection for her students is very much maternal.

Jay has been the director for two years, while the program has been in operation at Rise for seven years. Upward Bound is a fifty-year-old federal access program that came out of the War on Poverty, in 1964. The Rise UB serves 60 students in the $10^{\text {th }}-12^{\text {th }}$ grades. The community center is a large facility that takes up an entire city block. Upon entering the modern facility, through revolving doors, you must first check in at a large reception desk, and the receptionist calls to announce you. On occasion, the reception desk is surrounded by high school aged students who are chatting excitedly with the person manning the reception desk. Visitors are escorted by the individual that they are visiting and have a choice of taking either the stairs or the elevator to the upper floors. The UB office is a medium sized room with two desks, as well as a table and bookshelves lining the walls. The door has a window pane where students often peek through before entering the office. The director sits at the desk furthest from the door, and the coordinator sits at the desk near the door. In addition to the office space, the UB program uses classrooms as well as the computer lab, in the community center, for program activities.

The Rise Upward Bound program serves 60 students on average. The program provides tutoring, college tours, cultural activities and field trips. The students in the program are firstgeneration, as well as continuing generation. Two-thirds must be low-income, based on U.S. Department of Education guidelines, and first-generation, defined as the first in their families to 
earn a four-year degree. The program employs certified teachers and graduate students to facilitate Saturday courses during the school year, as well as during the six-week summer program. Unlike many UB programs, the Rise six-week program is not operated on a college campus, but at the community center.

\section{Mark}

Mark is the only a white participant, and is the program director of Catch, a communitybased sports program offering tutoring and college readiness. He answers my questions succinctly and discloses very little personal information. His tone is quite formal during our interview. Mark responds to my questions with very precise facts about the program and comes off as guarded, even when probed. I do find out more personal information during observations of him interacting with specific staff members. Mark relays that he has worked in "urban youth work" for over fifteen years. He worked for ten years in a sports program located in an eastern state, where they served middle school students in what he described as a pathways program. He seems to have a friendly relationship with some of the staff on his team.

Catch Serves students from low socioeconomic communities and engages them in sports training and competitions. Unlike the other programs within this study, CATCH is not primarily a college access program. It is a sports program with a college and careers mission. The program recently moved to a multimillion dollar facility which houses 3 classrooms, one large open office space for staff (with an executive space for the executive director), and the focus of the program is reflected by the half of the space being devoted to indoor courts. Students enroll in the program during middle school and are provide academic support and sports training through high school. Academic and social support continues through college and many alumni work or volunteer while in college or during their summer breaks. 


\section{CHAPTER V: THE MAKING OF A COLLEGE STUDENT}

\section{Introduction}

In this chapter, I describe how the contexts of college access programs are guided by their program leaders. As a point of clarification, although students enrolled in college access programs are commonly known as participants, for the purposes of this study the program directors that were interviewed are referred to as participants, and members of the populations that they serve are denoted as students. First, I describe directors' assumptions of students' needs as well as how programmatic objectives towards meeting those needs are implemented. I then examine the influential factors of program practices and the valuation of these factors based on the perspectives of the participants of this study. Finally, the planning, implementation and funding of program activities are explored. Utilizing a CRT framework to approach my analysis, I documented how the research based college access ideology, discussed in chapter 2, manifests to advance deficit thinking and notions of whiteness in the practices of college access program directors. I begin with findings related to research question 1.

\section{Research Question 1A}

What are the underlying assumptions that college access administrators have about the African American students that they serve?

\section{Composite of Blame}

Whiteness as norm describes a socially constructed standard comprised of knowledge, activities and orthodox beliefs ascribed to the white elite class of American society (Guess, 2006). Assumptions of college access directors concerning the students that they serve are riddled with deficit thinking and idealized whiteness. Research has suggested that low-SES, firstgeneration and African American students lack the knowledge and resources to articulate a clear 
vision of how to align their education goals with their career expectations (Carter, 2005; FarmerHinton, 2011). Working towards actualizing the goals of college prep programming to increase degree attainment and postsecondary success for underserved students is appropriate considering the continued disparity of degree attainment between African Americans and whites. However, research on college access programs has suborned a deficit thinking ideology (Valenica, 2010) leading to program practices rooted in victim blaming. This pattern of victim blaming under the guise of thrusts for preparation surfaced as I interviewed and observed participants for this study.

While collecting data, I very quickly discovered that the participants of this study uniformly subscribe to the college access ideology prevalent in research. They each emphasized student level remedies in response surmounting barriers college access. When participants were asked to describe the students that they serve and their needs, the "blame game" began. Students' needs were identified in alignment with assumptions of the extant college access literature. They immediately sorted students by race, socioeconomic level and first-generation status. Needs were implied by demographics with the rare distinction between the two. Jay described her students by race and income. She turned to the federal TRIO eligibility requirements to relay the identities and need of her students:

My students are African American they come from... some specific schools and geographic locations...So most kids are African American and from the south side. We are required to have two thirds be low-income as defined by the Department of Education, and first-generation defined as the first to attain a four-year degree... so African American students who are trying to get into college, and most are first generation aspirants. And even some who are second generation aspirants. 
Peter's description also led with the race of his students, then went on to highlight the academic aptitude of students who are handpicked via a rigorous application process:

So, we work exclusively with African American students. We are a program where students apply to us in eighth grade, and we use an application process that allows us to really examine the family's income. Our goal is to work with highly motivated students who are not students- who are kind of on this divvy of I don't know if I want to go to college, or I do want to go to college. We're looking for those students who know that college is the path.

Rochelle immediately stated the socioeconomic status of her program's participants, and included remarks pertaining to their educability:

...we serve students that are classified low-income. Most of them are first generation, not all...majority of our students, are evenly split, majority African American, Hispanic, Latino students. They come from all over the city... and their needs vary. So, we have students that are testing in the 99th percentile on tests and we have some that severe, severe learning challenges., and who are grade levels behind, due to either being in a poor school at the beginning of their education, or just because they have learning challenges that they were born with, and that they have to overcome.

Sam emphasized the diversity of the population that he serves and named familial structure, race and income status as a display of this diversity.

We serve a diverse student body. and by diversity the way we define it is through a number of areas. We define it like diversity in student experiences...Some come from single family households, um others have another parent or guardian that watches for them, are really the main caretakers because their main dad or mom are you know 
somewhere else or out of the picture... Roughly about $75 \%$ of our students are- will be first generation in their families to go to college. About $75 \%$ of our students are also of a low-income background, and about 50\% of our students come from an underrepresented background. Whether that's African American or Latino students.

Mark alluded to socioeconomic status using free lunch status and neighborhoods of origin to describe his students:

Mark: From the south side of [town]. In ages, sort of grades fifth...through college graduation...there's a variety of needs that we fulfill...we recruit them...from our partner schools. And, we establish those partner schools... [using] a certain typical bench mark. We'll search for a school, we'll partner with a school that's been identified...usually by a certain percentage of free or reduced lunch, and ...tryin’ to identify kids...you know often it's sort of middle of the road kids where academically they may be doing ok or they may not be doing, you know C and B students.

Inherent in these descriptions is the belief that, by nature of their race and SES status, these students need college access programs to gain the privileges of whiteness.

Program literature also utilized deficit language in describing services and students. The program flyer for Jay's program listed a goal to increase the rate of completion of secondary education and enrollment in college, and offered cultural enrichment as a service in support of that goal. Eligibility for her program required that students "possess potential for success in postsecondary education (Rise Upward Bound, document).” Peter's program literature refers to "economically disadvantaged African American[s];" and the mission of Mark’s program claimed to “engage underserved...youth” Participants persistently used victim blaming conventions when discussing students. 
Achievement Gap. Participants used the achievement gap to anchor their assumptions of the need for college access programs. Mark refers to the burden of resolving the achievement gap, and sees his program as a necessary aide for schools, “...the achievement gap is so big that schools started recognizing that we can't do this alone. ...we need community partners that are really, really strong. And this is where organizations like Catch fill the void.” Peter refers to lack of academic preparation as an outside force that inhibits college aspirations, "Some of our kids aren't prepared academically...You know. That's a force. They're just not ready for the work load.” The achievement gap was constructed to conceptualize the disparate educational outcomes among marginalized students and their white counterparts and accounts for the education debt of resources not invested (Ladson-Billings, 2006). The stigma associated with students who are affected by the achievement gap is propagated in college access program practice by calling out student needs and ignoring the fault of an oppressive educational system in meeting the needs of marginalized students. Participants used college access work as a process to fill the "void" in bridging the achievement gap, without considering the role of white supremacy in sustaining the gap.

Low-income. The income indicator was used to capture social and cultural deficits concerning students' need for college readiness assistance. SES was stated explicitly in program goals to serve "low-income students", "economically disadvantaged", students who receive "free or reduced lunch”, or students with "limited resources.” Program leaders inferred needs of SES students based on circumstances beyond their control, such as residing in under resourced communities. Peter spoke to his perception of challenges in motivating students from the south side of town, 
...when they go back to their reality of their neighborhood, and it's- the majority of the people are not speaking the same language that their speaking, or they're not encouraging this young person to want to aspire to be more... So, it's encouraging to know we have some young people who are saying hey I want to be different, I want to do more.

Social stratification hinders the educational outcomes of low-SES students as it contributes to lower quality schools and fewer resources for economically disadvantaged students (Valencia, 2010). Sam and Rochelle both specifically make a differentiation between students attending elite schools and "neighborhood schools" for elementary and high school education. This differentiation points to a "the haves and the have nots" perspective of the students that they serve. Low income students are sorted into the have nots in terms of cultural capital, social capital and academic abilities associated with privilege. Rochelle's program espouses in the annual report that they provide an alternative path to students that come from neighborhoods "that prevent many others from attending college or even graduating high school."

Ironically, Peter and Sam both have programs that require a certain amount of economic capital in order to participate. Sam's program serves student across the city and does not provide transportation or meals. He spoke of staff donating to support students whose attendance was hindered by a lack of bus fare. Peter quantified SES status by expected family contribution (EFC):

...we have an application process, similar to the FAFSA, where you uh divulge all your financial information. There's a special calculation and based on that it tells us what you can afford as a family to pay. So, we're really looking for families who again cuz this is not a full scholarship, we're looking for families who are not necessarily the poorest of the poor, it's like the EFCs are zero. But definitely not looking for the folks who have 
EFCs of ten thousand or more. So, our average family has an EFC of under two thousand dollars. The average income is about thirty thirty-two thousand.

However, the mission of Peter’s program includes a statement on serving economically disadvantaged students. In this scenario, SES assumptions are fluid and are used in service to the program mission, although they are unaccounted for in program objectives. I will address the tensions between the missions and objectives of college access programs later in this chapter. At this juncture, I will continue my exploration of victim blaming and address the assumptions held about first-generation students.

First-generation. Students’ first-generation status amplified participants’ focus on student deficiencies acting as inhibitors to the ability to access and thrive in college. In addition to low academic performance and community level problems, an absence of familial awareness of college pathways knowledge, and lack of exposure to college culture were named as barriers for first-generation students. A lack of social capital related to whiteness undergirded the victim blaming assumptions concerning these students. Peter and Rochelle spoke of the need to "coach" and "train" parents on how to support their children on the college pathway. Rochelle described parents' as lacking enough life experience and resultant critical thinking skills to guide students through life challenges,

I'll have to say since our parents have never been in college or a professional setting, um they're not aware of what some of those- what challenges look like...Or when a child comes up like, oh this working is so hard, and they want me to get up early and things like that, and the parent's like well you don't have to. No, but you do. [laughs]. But you do have to do this. But if uh let's say mom's never really worked before, then she can't 
really tell you this is what normal working hours look like, and this is being tired after you come home from work is a thing that happens.”

In discussing challenges of her work in access, Jay noted students' lack of exposure to the dominating college culture,

We're doing what the continuing generation family and extended family just do at dinner, at Thanksgiving, at Christmas, Thanksgiving...Oh uncle so and so, how are you? Oh yeah I'm good. You know I went to my U of I reunion, saw my friends... Oh I went to my Montana, you know wherever you...Oberlin. Oh, ya'll here's my college roommate. He's getting married. All these things come together for, particularly the more generations you have and just that exposure...mom's having her reunion. We're going with her to U of I...I went to the University of Wisconsin. We're going to Wisconsin. Um and that conversation is missing... When that happens over someone's life, over fifteen years, and we're trying to do this in like a couple of years...it's different. It really is different. The first-generation label automatically implied that students lacked access to information on college, and were also ignorant of the concepts of college culture. Participants viewed their programs as leverage for acculturation to the experiences of the dominating culture.

Study participants stressed the need to develop students’ social skills. Sam proclaimed that his program cultivates students for selective enrollment postsecondary institutions Jay argued, "I think we're so test driven that the only thing we have time for is the ACT but, it's a lot of social skills. A lot of social nuances that I think kids need to practice.” Assumptions that firstgeneration students are disconnected from college knowledge due to a bankrupt social network deny the historical exclusion if marginalized groups from higher education (Patton, 2016). Mastering the "social nuances" of the orthodox class that has been included and welcomed into 
higher education spaces since their inception, heightens the impact of the subjugation of students who have been historically excluded.

African American Students. Four of the five participants of this study reported serving solely or predominantly African American students. The fifth participant, Mark, never specified race as a descriptor. However, I observed his student population to be African American. When discussing college access barriers and student needs, there was virtually no mention of racism or structural oppression. Jay used program activities and informal conversations with students to raise issues of race and racism. However, she put the work on students to be aware and ready for racialized barriers on campus., "you're going to have to bridge some gaps and certain racial issues on campus. You try to talk a lot about race and racism on campus, and what they- you know encounter- what that looks like, how might they respond. We have other kids talk to them.” Meritocracy was the salient thread of conversations on providing access opportunities. Rochelle stressed that she expected her students to work hard and learn to be accountable, as well as demonstrate soft skills for the workplace to be ready for postsecondary success,

And that was where my mindset was when I came here. It was I'm going to teach you the skills needed, so that I can let you go into the world, and you can be successful. Where um and so a lot of the push back was I was too difficult on the kids. I was too tough. And um certain things that I asked like simple rsvp when we have outings every month. You need to learn how to rsvp. That's just part of how the world works.

Her expectations that students meet her demands to be considered "ready" for life after high school reflected a constructed notion of “smartness” (Hatt, 2012).

Ignoring the effect of racism on the historical denial of college access, as well as assumptions of lack within these students are undergirded by standards of whiteness. Whiteness 
is recognized to mitigate life chances in American society (Guess, 2006). Inoculations of whiteness are valued to groom students for actualizing the American dream. Rochelle's program was started by a group of college friends [inferred non-minoritized] who wanted to give students, “... privileges that we [the founders] had that we need to give to students who don't necessarily have access to get them, to be as successful as we are.... they would say they had a network...They had access to quality education... Others said exposure.” This meritocratic perspective neglects the racist higher education system and the history of racialized admissions practices (Patton, 2016).

It is of interest to note that the same labels and sorting assigned to students were also used by three of the five participants to describe themselves. As revealed in chapter four of this dissertation, Rochelle, Sam and Peter are all first-generation students of a minoritized race. These three also went in to detail about their uneven pathways to college, I asked them to tell me about themselves. Their assumptions about the students that they serve are influenced personal experiences.

Defining student needs via demographics align with deficit based research, participants presented low-income, African American, first-generation students as categorically deficient. In addition, this perception of students compartmentalizes them by the socially constructed circumstances of race and class. CRT recognizes race as a social construct with no connection to genetics, that society invents and wields when convenient (Delgado \& Stefancic, 2012). According to Valencia (2010) person centered failure ascribed to group membership "absolves institutional structures and inequitable schooling arrangements that exclude students from optimal learning (p. 18).” Failure to capture the causal factors of student needs overshadows the 
circumstances brought on by systemic racism. Resultantly, this victim blaming approach illuminates alleged deviance in need of redemption.

\section{Research Question 1B}

How do these assumptions play out in the actual practices of the program services?

\section{Road to Redemption}

College access programs use prescriptive activities to assist students in working towards parity in education. Program models of directors participating in this share common curricular mechanisms to build students readiness skills. Their approaches to evoking college readiness are defined by two overarching thrusts. The first thrust academics, includes tutoring, academic enrichment. The second thrust cultural exposure is cultivated with mentoring, funding to enroll in private elementary and secondary school, contact with postsecondary culture, and field trips. Participants work to accomplish these thrusts, blind to the educational oppression that created the need for access. Despite school failure plagued by lower quality education and insufficient resources (Ladson-Billing, 2006; Valencia, 2010) college education is perceived as fail-safe step towards the American dream. Rochelle voiced her role in supporting college access,

Social-emotionally, financially, and academically. So, when we say working to your full potential whatever that is, working backwards to get you to that point. So that means making sure that you're in a school in elementary and middle and high school, that's gonna prepare you academically.

Participants recognized their programs as equalizers to opportunities for social mobility and success. Commenting on the challenge of conveying the import of his program, Mark stated, “We're changing kids’ lives.” Participants’ self-report in combination with respective program literature asserted that these programs change the life trajectory of the students who take full 
advantage of what is offered. The annual report for Rochelle's program asks readers to imagine being a child with limited opportunities who want to be the first to go to college, but neither you or your parent can fathom what is involved in achieving that goal. The passage goes on to proclaim the transformative power of the program in helping such children reach their goals and break the cycle of poverty. This is an example of how students' options for upward mobility are assumed to benefit from the life changing impact of college access programs. The programs lay the course and the students do the work. The road map to collect the tools and skills to access opportunities for achievement is marked by the components and curricula of their programs.

Acadmics. Academics are weighted heavily by participants. There are very specific guidelines for participation in tutoring sessions, academic enrichment courses and GPA requirements. Each of the programs has a structured academic component. This component consists of academic courses as well as tutoring. ACT and/or SAT exam prep is included in the academic piece. Jay, Mark and Rochelle offered regular tutoring in their programs, as well as academic courses during specified times of the year, such as summers for Mark and Rochelle, and on weekends and in summers for Jay. Peter and Sam offered tutoring as needed, with a primary focus on academic courses to supplement students' regular school curriculum. Peter's program had a clear standard for students,

So, we have a minimum GPA expectation. So, students have to have at least 2.8, I told you our goal is 3.3...If a student falls below a 3.0, then they go on our watch list, and we have program managers that will set up an acad- what we call an academic counseling session with the student, and the parent, and/or the mentor. And then in those academic counseling sessions, we are trying to get to the root cause... So, we really work to raise the bar of expectations for the students. 
The push to ensure that students are ready for college was a prominent concern of participants. Reporting of academic progress as program requirement is used to monitor students’ performance. GPAs that fall below the minimum requirement can result in probation and can possibly lead to expulsion for Peter’s programs.

A banking model (Freire, 2009) of supplemental education is used to acclimate students to norms of whiteness typically afforded a quality education. Students are inundated with information to levy "smartness” (Hatt, 2012). Academic elements are mandated in each program. Table 1. shows Program readiness goals and activities by participant.

\section{Table 1}

Program readiness goals and activities by participant

\begin{tabular}{lll}
\hline Participant & $\begin{array}{l}\text { Readiness } \\
\text { Goals }\end{array}$ & Activities \\
\hline Jay & Academic, social and & Tutoring, field trips, college exposure \\
& recreational opportunities & \\
Mark & Academic achievement, & Sports, mentoring, tutoring, academic enrichment, \\
& access to opportunity & field trips, college exposure \\
Peter & Enroll, persist and graduate & Scholarships, mentoring, academic enrichment, \\
& college & college exposure \\
Sam & Access to selective & College access workshops, academic enrichment, \\
& enrollment college & leadership development, field trips, college \\
& & exposure \\
Rochelle & Build academic foundation & Tutoring, field trips, social and financial support, \\
& and life skills & college exposure
\end{tabular}


Jay spoke of making her students aware that they may encounter differences in college such as having a gap in preparation. She took a heterodoxic approach to her academic component and pointedly ensured that her program themes and materials were focused on African American culture. She acknowledged hegemonic standards of preparation, but also embraced the cultural identity of the students that she served. When I came out to observe her, the theme was 1968, and each module was related to an event that happened in African American culture in 1968, with a specific course titled "Power, Privilege and Difference.” Sam's program offered race centered courses on Martin Luther King Jr. day and in the month of February respectively.

In contrast, Peter reported that his students requested reading African American literature in their enrichment courses so that they could see themselves in the material. Peter commented that the request was honored, even though at the time they were reading Catcher in the Rye, a "classic" that they would read in school eventually. Success was defined by position, careers, earnings and/or promotions. The participants all subscribed to the myth of meritocracy (Carter, 2008), believing that if students work hard they will succeed in college and grab hold to the American dream. The myth of meritocracy declares hard work and accumulating accolades as the route to life success. This myth ignores the impact of racial oppression and subjugation on marginalized groups assumed to be inherently unfit no matter how hard they work. Peter's description of serving “motivated students' frames students as having enough merit to warrant college access:

Our goal is to work with highly motivated students who are - not students who are kind of on this divvy of I don't know if I want to go to college, or I do want to go to college. We're looking for those students who know that college is the path. Like they may not 
know how to get there, they may not know what schools they want to go to, or what schools are even possible, but we are working with those highly motivated students that are already kind of in that momentum.

The myth of meritocracy is enforced by the high valuation of academic achievement. Participants create activities and set standards to lead students in the hard work of achieving the American dream. Students are called to be self-advocates and labor to overcome the effects of school failure (Valencia, 2010) and the education debt (Ladson-Billings, 2006). Participants saw themselves, as well as the larger program community including program alumni, mentors and staff as guides to assist students in pulling themselves up by their boot straps.

Cultural Exposure. The racialization (Guess, 2006) of college readiness is embedded in program director's implementation of processes designed to expose students to a culture of whiteness. Collecting accoutrements of white privilege acts as an indicator of upward mobility. Cultural exposure involves participation in activities and experiences to augment student's social status. This exposure plays out in connecting students with mentors who have ascertained and perfected whiteness, to bolster social capital; and taking students on field trips framed as cultural activities to increase their cultural capital. Next, I will examine the ways in which participants regard cultural exposure as a tool to support social mobility and successful outcomes in access.

College access programs directors acted to familiarize students with the knowledge and cultural capital aligned with aspirations of the dominating culture. Jay expressed, "in addition to the academic courses we provide cultural exposure- going to museums and plays and things like that. Expand students' cultural horizons.” The need to expand cultural horizons with exposure was important to Mark, who shard that his program takes students on "intensive field trips.” An example of a trip for his students is a visit to a local museum. Likewise, Sam's program 
curriculum required students to attend cultural outings every quarter to foster “cultural awareness.”

Participants value cultural activities in access programs to assist students in gaining social capital. Additionally, college exposure via college tours and college fairs are fundamental to their programs. Rochelle noted that she wears a different college t-shirt each week to programs to spark conversations about the respective campus, as well as provides an intensive college boot camp. Participants seek to replicate the impact of social networks common to affluent white communities. Peter stated, “The college and career readiness is really important to us. So, we're giving the students opportunities for exposure and immersion. Jay holds a similar view, The goal of the program is to provide exposure to college culture, to prepare students for college applications, um and uh college applications, financial aid applications um and then to provide support uh other academic support you know through tutoring or by offering some of our classes to uh help students uh with uh getting some extra learning about different topics.

Participants views on their program activities as germane to providing social and cultural capital required to assimilate to whiteness. Mark commented on how his program broadens the culture of students,

They're meeting a lot of people who they wouldn't've usually- you know we're taking them to the Guggenheim to do mock interviews. They're learning how to shake hands and make eye contact, and do all these things and it sort of accumulates in an amazing way. ... We just took our fifth graders on a college visit last week. You know to have that luxury. So, I think parents find it very, very effective and like, you know broadening their world view and I think they end up feeling very, very lucky...They feel like they won the 
lottery. Because they're not paying a dime and their kid's going all over the country [laughs] learning new things.

Participants offered students opportunities to achieve social parity with white counterparts with a college education. Peter viewed preparation for college success as the best way "to prepare students to be successful in life.” Peter's statement represents the participants' belief in a college access ideology that prepares students to assimilate to whiteness and disregards the impact of racism and white supremacy on access, admissions and degree attainment (Harper et al., 2009).

The racialization of college readiness ignores the impact of racism and white supremacy on the college experiences of African American students. In terms of barriers on this pathway, three of the participants recognized systemic issues that will inhibit students' upward mobility. However, racism was rarely overtly acknowledged or mentioned. Apart from Jay, who relayed the goal of explicitly talking to her UB students about class and race issues, in relation to college culture. She felt that students needed to talk about the differences that they will encounter interacting with students from rural areas and backgrounds generally different from them, “... you're going to have to bridge some gaps and certain racial issues on campus. You try to talk a lot about race and racism on campus and what they encounter, what that looks like, how might they respond.” Jay used conversations about race to increase student awareness. I contend that raising student awareness of racism furthers the racialization of college access by placing the blame on students for being "other.” This reinforces the superiority of whiteness and teaches students how to navigate on the margins. Furthermore, using cultural enrichment and cultural exposure as a tool to promote college readiness overlooks the rich cultural wealth that these students possess, that can serve as a valuable mechanism to advancing diversity on the college campuses that they attend. 


\section{Research Question 2}

How do the explicit goals of college access programs align with and/or contradict the actual practices of the programs?

\section{Principles of Pathways}

I acknowledged earlier in this dissertation that there is no normalized model for college access programs. With college admissions as the overarching goal, program leaders leaned to a variety of resources to guide strategies for readiness. Table 1. lists the readiness goals and related activities of the college access programs led by participants. There is a common theme to provide academic support and cultural exposure to cultivate readiness. The design and objectives of such activities were similar across programs in this study. Furthermire, participants held common assumptions about the needs of the students in their programs, rarely placing

culpability on higher education instituions or underresourced K-12 educational systems. Instead partnesrhisps with these programs are used to supplement college access programs in their work of bridging the gap.

Participants name schools as partners in alleviating barriers to access, disregarding the schools’ (K-12 and postsecondary institutions) culpability in creating and sustaining barriers. Each participant led a program that is in partnership with elementary, high school and postsecondary institutions. Peter and Rochelle employed partnerships in providing scholarship assistance for their students to leave the public-school system and attend private schools. Sam's program operated in partnership with a private university and leveraged that partnership for resources such as program space and faculty to teach academic enrichment courses. Partnerships with institutions that create and sustain the need for college access programs may account for negligence in challenging the oppressive role of their partners. Instead, there is a focus on 
correcting student deficiencies that diminishes the institutionalized and structural barriers that perpetuate racism and oppression.

The effects of systemic racism are operationalized in underfunded schools and under prepared students (Ladson-Billings, 2006). This issue of underpreparedness was not only stated as motivational to doing college access work, but was also reflected in the mission statements of the programs that they lead. The programming that is offered by their respective programs is viewed as an open door to access new opportunities and a better life via a college education. As such they see themselves as gatekeepers to postsecondary success.

Gatekeepers. Acting in the role of gatekeeper, directors create pathways dynamics and make determinant decisions on readiness. Beyond college readiness goals, participants supported persistence through college. While the UB program that she directs is academic focused, with tutoring and weekly academic courses being central to the curriculum, Jay sought to prepare students beyond the classroom, "I’m trying to think more about the bigger picture.” Her goal was to “... provide help to ... build your own social capital and competencies, so that you can be successful in college.” Mark’s college access focus was getting students ready to get through college, after access is attained. During his work over the last ten years in sports programming combined with academic support, he observed a shift in access goals, My experience has been um kind of one noticing over the ten years the sort of bar kind of move from access itself from getting kids to college which in the early years if you get a college acceptance it was amazing and it was big. And now it seems that getting kids into college is, not easier but it's not the goal anymore. It's getting them through college and then that has moved ah uh that bar has moved a little bit. 
Jay also noticed that getting students through college has become an implicit goal for the college access landscape. However, she expressed that goal is too lofty to be taken on by college access programs. Both Mark and Jay have staff devoted to alumni of their access programs who are in college. Rochelle’s program recently made college persistence a goal, "Um and we found that those who stay in contact with us and receive our support, persist. Those who kinda go on on their own, definite have more trouble...um persisting, um through college.” Participants recognized that the academic preparation and cultural exposure that they provided are not sufficient to assure degree attainment. In response, they deemed it necessary to provide additional supports, extending their access work post college matriculation. This additional support continues to emphasize victim blaming and turn a blind eye to the racist nature of college cultures that have traditionally excluded low-SES, African-American and students whose families were denied the opportunity to create a legacy of college educated members.

Participants used terms like saving, changing, solutions and opportunities to describe how their work affects barriers to access. Rochelle's shared sentiments on serving students in access programming,

And um I was just say well why don't they all want to go to college? Why don't they all want to do well? Wh-. You know what I mean? I know that for me it was my only goal in life was to get out of poverty. That's all I ever wanted was to not be poor. And so, I just didn't understand why somebody wouldn't want to work hard to do that, but then I had to realize, everybody's not you and everybody can't be saved.

Acknowledging structural problems in the education system, the participants fortified their roles as gatekeepers as wells saviors' objectives to produce students that fit the ideal of college readiness. Mark stated, 
Our kids had a huge gap you know achievement gap and they, they don't know their multiplication tables can we help with that? So, then we started building curriculums out for math. Curriculums for reading. To sort of help close that.

The myth of meritocracy fueled their work in saving students from being swallowed by the achievement gap. Students that work hard enough can overcome the effects of systemic racism and oppression, to actualize the American dream. Peter explained the effect of his program for students who take full advantage, "For me, and for the organization...It's all about elevating our students so that they impact the community that they came from, and you know programs like Beyond Ready hopefully, eventually won't be needed anymore. That's the goal.” By championing upward mobility via merit coupled with objectives to enhance their community of support, participants help students create a dossier of readiness aligned with the norms of college culture.

Social Support Net(worth). The accumulation of social capital has been designated as being of import in college access (Farmer-Hinton \& Adams, 2006). Establishing a college savvy social support network was fundamental to participants. The existence of their programs surrounded students with a reputable community of people in the know. The accumulation of social capital is a measure of college readiness, judged by who students know, and the perceived value of the social capital wielded by those in the students' network. I have termed this measure social support net(worth)

Mentors. Mentors played a role in disseminating information and modeling the habitus (Bourdieu, 1986) of the college educated class. Acculturation to alternate social and cultural norms helps students shed the qualities and characteristics of being "other." Mentorship is used as a guard rail keeping students in check on the college pathway. Peter and Rochelle had a 
formalized mentoring component, while Mark and Sam used mentoring in a more informal manner. For Peter, "the mentors are an extension of our program. So, when students are interacting with their mentors, you know we consider that interacting with Beyond Ready, because the goal is for the mentors to be sharing the exact same messages that the [our] staff will be sharing as well.” Sam shared thoughts on establishing structured mentoring,

You know that's one thing that we, as we think about 2.0...the next version, well how do we really build a robust mentoring opp- uh program for students. You know how do we really get our alumni to be in touch with our current students, and build this path and this frame where, framework where the students are connected still with other underclassmen that are relatable to them. Cuz we have some unofficial mentoring, mentor-mentee relationships from other older working adults.

Jay also expressed that mentors would be additive to her program, "I'd love to be spending more time with having our students have more mentors.” Mentoring was talked about, but much like college access programs themselves, there was no official model.

Even when mentoring was implemented as a formalized practice, there was no systematic approach. The mentors in Peter's program were managed by the advancement team of his program with an expected financial commitment and time commitment, "The mentors have some responsibilities in terms of interacting with their student at least twice a month. Seeing them at least twice a year.” Rochelle saw her mentors as meeting the programs goals of creating a network, and used mentors in assisting students with career related objectives such as creating resumes and helping students learn how to dress professionally.

While mentors had an assumed additive value, parents were not always valued. The role of the parent in affirming the efficacy of the program impact was common. However, 
participants regarded themselves as acting in the role of co-parent for students, if not parent. Parent trainings and coaching were voiced as a means to get them on board the access train.

\section{Conclusion}

This chapter examined the ways in which participants' used academics and cultural exposure to teach students to adapt and revere tools and skills that advance standards of the white elite. These standards were highlighted in contrast to their deficit based descriptions of the students served and their needs. Program literature used deficit labels to describe students in their missions and recruitment literature, and advertised services and outcomes focused on acculturation. Both the standards of whiteness as norm, and the victim blaming assumptions that bleed into the tactical work of meeting program goals and objective are a direct reflection of the research based college access ideology. 


\section{CHAPTER VI: CONCLUSIONS}

\section{Discussion}

I am a proponent of college access programs. I feel the need to make that clarification as my analysis has been highly critical of the college access ideology. College access programs focus on improving the life and educational circumstances of students with an emphasis on what Freire (2009) describes as a banking model of education. This approach employs activities that fill the students with methods of improvement with little to no focus on the problems that undergird the problems of access. It is not enough to acknowledge disparity in enrollment and completion for African American students as an impetus to research the barriers to college access for these students. It is necessary to call out the systemic racism and institutional cultures steeped in white supremacy (Patton, 2016) as a primary inhibitor to college access and success for African American students. Furthermore, it is necessary to dismantle the standards of whiteness propoagetd by the popular college access ideology. CRT scholarship is an optimal avenue to disrupt notions of whiteness as norm in college access. The barriers to access that underserved students face are steeped in deficit thinking and standards of whiteness as center. The college access ideology focuses on preparing students to meritoriously earn access to college and fails to acknowledge the systemic and structural barriers that limit access. Educating program leaders on CRT discourse on whiteness and racial realism - acknowledging racism as "a means by which society allocates privilege and status (Delgado \& Stefancic, 2012)”- can have an effective impact on disrupting deficit approaches in program design and curricula.

Students' needs serve as the justification for the necessity of college access programming. Participants highlighted student deficiencies to bolster the case for the programs and services that they offered. Participants reliance on deficit entrenched research leads to 
preparing underserved students to adapt to the status quo of a college culture that was established to exclude them. College access programs seek to mold students to fit the idealized standards of whiteness. Program leaders abandon the opportunity to disrupt the belief that low-income, minoritized and first-generation students are bankrupt of capital that can serve them in designing and attaining individualized aspirations of success. There needs to be more efforts to empower students rather than teaching them to effectively exist on the margins. Yosso (2005) asserts that the nature of education is contradictory in working to oppress and marginalize, while maintaining the potential to emancipate and empower. If college access programs are to effectively bridge the gap between college readiness and college admissions for underserved students, program leaders must shift from a savior pedagogy to one of liberation. Earning a college degree by shedding or shrouding individual culture contradicts espoused goals of nurturing students to achieve their fullest potential.

There is a prevalent goal of cultural exposure in college access. An alternate approach would be to celebrate the resources within the communities of underserved students. The celebration of the students' personal history and rich ethnic culture can act as means of empowerment and personal development. A focus on enlightening students to work against the policies and structures that have been denied or limited in their own communities can increase awareness of the education debt (Ladson-Billligs, 2006). Current goals of the college access ideology focus on readiness defined by academic success and appreciation of the dominating culture, while the student remains to be seen as other. Students should be armed with the tools to navigate racialized college climates while embracing their own culture. Preparing students for assimilation to the dominanting culture on college campuses inhibits opportunities for diversity via infusing the environment with the students' cultures and experiences. The small amount of 
time a student is "exposed" to the habitus of the dominating culture while participating in a college access program does not, cannot, overshadow the lifelong experiences of the student and the cultural wealth that they inherently hold.

The college pathway uses standards of whiteness as fence posts. Program leaders work to change the trajectory of students' lives with rigorous academics and cultural exposure. The potential to trigger success with academic interventions is supported by the notion of the achievement gap. The achievement gap has become code for the effects of historicized racism and oppression of underserved students on disparate educational outcomes. Valencia (2010) describes the inequitable distribution of school resources as school failure and Ladson-Billings (2006) coined the term education debt to tease out the contributing factors of educational disparities for low-income and minoritized students. Research and practitioner based efforts to resolve the effects of these events within college access are often comprised of student level fixes.

Researchers, policy makers and college access program leaders must begin to map backwards from research on African American college students and begin to prepare students for the college experience in and outside of the classroom. Namely social life, and how they may be perceived by faculty and non-African American classmates. This can be addressed by discussing issues related to culture and identity, and building a strong sense of self pride and resiliency.

Many students of color who succeed, cling to an imposed standard of achieving the American dream and must sacrifice their own culture to do so (Shapiro, Sewell \& DuCette, 1995). By promoting the ethnocentric culture within educational contexts, students learn to deny the value of their own culture. If they want to succeed, they must adapt and assimilate to the popular culture. College access research focused on cultural and social inadequacies teach 
students how to fit in. This mutes the voices and experiences in the classroom that invite multicultural perspectives.

Villalpando and Solorzano (2005) execute a review of the literature that explores students’ culture as a component in college preparation programs. This literature synthesis is focused on scholarship that explore college transition of students of color who have participated in precollege programs that include culture as a key factor. The authors contend that while most research utilizes cultural capital as a theoretical framework, cultural wealth may be a more accurate framework. The authors' reconceptualization of cultural capital into a definition of cultural wealth aligns with CRT goals of shifting from white as center in college access research.

With a primary focus on preparation via assimilation, program leaders design programming focused on habituating students to survive within a higher education system rooted in racism and elitism. Curative measures focused on the problems within the student, ignore the racially hostile environment of college campuses.

\section{Implications}

The binary view of success held by college access scholars and practitioners embraces college education as the only route to improving the life circumstances of underserved students. College access ideology should be reconceptualized to be inclusive of the cultures and values of the students that they were created to serve. Working towards assimilating students to traditional values serves as a disguise for racism (Yosso, 2005). College access practitioners should begin to work towards embracing the cultural wealth of their students. Furthermore, they can use their professional authority in championing for the expansion of the standardized norm of college student to include the stories and experiences of marginalized students among researchers, 
funders and institutions of higher education. Work to shift from whiteness as center or standard, should also include dismantling common conceptions of smartness. Funders of college access work should allocate money to support counter storytelling and ahistoricism efforts of CRT (Delgado \& Stefancic, 2012) to educate program leaders on the truths of the white supremacy that beget access problem.

\section{Future Directions}

College access issues deserve a place within the college success conversation. Mapping backwards from the research on college culture centers and CRT discussions of student development theory, will establish a foundation for access directors to build programming and affect policy that support a shift in donors' guidelines beyond quantities outcomes and "glory stories.” Research aligning college access issues with discussions on student development of African American students will support a more seamless pipeline to and through college for these students. College access is touted as the way out for underserved students. The apparent need for a way out implies that their communities are hopelessly deficient, as opposed to systematcially oppressed. Rather than using college as a way out, students should be encouraged to seize the opportunity to work as activists and champion for increasing resources for their communities. We must teach African American students to take pride in who they are and where they come from, and prepare them to be critical thinkers and change agents who will work towards promoting the rich traditions and cultural wealth (Yosso, 2005) that nurtured them to shape and achieve their ambitions.

\section{Future Research}

Given the opportunity to repeat this study, I would broaden the scope to include interviews with program alumni, parents and donors. I suspect that the perceptions and 
assumptions regarding college access efficacy and perceptions of success would reveal a richer story with the input of more voices. A comparative exploration of the expectations of parents and donors, in conjunction with an evaluation of the stories of program alumni, may reveal tensions between stated program goals and the actual outcomes for students’ once they are enrolled in college. 


\section{REFERENCES}

ASHE, (2003). Postsecondary opportunity. ASHE-ERIC Higher Education Report, 30(2), 1-41.

Baldridge, J. V., Curtis, D. V., Ecker, G. P., \& Riley, G. L. (2000). Alternative models of governance in higher education. In M. C. Brown II (Ed.), Organization \& governance in higher education (5 ${ }^{\text {th }}$ ed.; pp. 128-142). Boston, MA: Pearson Custom.

Banks, C. A. (2009). Black women undergraduates, cultural capital, and college success. New York, NY: Peter Lang.

Bell, Jr., D. (1980). Brown v. Board of Education and the interest-convergence dilemma. Harvard Law Review, 93(3), 518-533.

Bergerson, A. A. (2009). College preparation programs. ASHE Higher Education Report, 35(4), 85-97.

Bergin, D., Cooks, H., Bergin, C. (2007). Effects of a college access program for youth underrepresented in higher education: A randomized experiment. Research in Higher Education, 48(6), 727-750.

Bolman, L. G. \& Deal, T. E. (2008). Reframing organizations: Artistry, choice and leadership. San Francisco, CA: Jossey-Bass.

Bourdieu, P. (1986). The forms of capital. In J. G. Richardson (Ed.), Handbook of theory and research for the sociology of education (pp. 241-258). Westport, CT: Greenwood Press.

Cabrera, A. F., \& La Nasa, S. M., (2001). On the path to college: Three critical tasks facing America’s disadvantaged. Research in Higher Education, 42(2), 119-149.

Carter, P. (2005). Keepin’ it real: School success beyond black and white. New York, NY: Oxford University Press. 
Carter, D. J. (2008). Achievement as resistance: The development of a critical race achievement ideology among Black achievers. Harvard Educational Review 78(3), 466-497.

Cohen, A. M. \& Kisker, C. B. (2010). The shaping of American higher education: Emergence and growth of the contemporary system. San Francisco, CA: Jossey-Bass.

Collier, P. J. \& Morgan, D. L. (2008). “Is that paper really due today?”: Differences in firstgeneration and traditional college students' understanding of faculty expectations. Higher Education, 55, 425-446. DOI 10.1007/s10734-007-9065-5

Conley, D. T. (2008). Rethinking college readiness. New Directions for Higher Education, 144, 3-13.

Corwin, Z. B., Colyar, J. E., \& Tierney, W. G. (2005). Introduction: Engaging research and practice-extracurricular influences on college access. In W. G. Tierney, Z. B. Corwin \& J. E. Colyar (Eds.), Preparing for college: Nine elements of effective outreach (pp. 113134). Albany, NY: State University of New York Press.

Crotty, M. (1998). The foundations of social research: Meaning and perspective in the research process. London; Thousand Oaks, CA: Sage Publications.

Dana, N. F., Dana, T. M., Kelsay, K. L., Thomas, D., Tippins, D. J. (1992, January). Qualitative interviewing and the art of questioning: Promises, possibilities problems and pitfalls. Paper presented at the meeting of Qualitative Research in Education Conference, Athens, GA.

Delgado, R. \& Stefancic, J. (2012). Critical race theory: An introduction. New York, NY: New York University Press 
Dennis, J. M., Phinney, J. S., \& Chuateco, L. I. (2005). The role of motivation, parental support, and peer support in the academic success of ethnic minority first-generation college students. Journal of College Student Development, 46(3), 223.

Denzin, N. (2002). The interpretive process. In A. M. Huberman \& M. B. Miles (Eds.), The qualitative researcher's companion. (pp. 349-366). Thousand Oaks, CA: Sage Publications.

Dilley, P. (2000). Conducting successful interviews: tips for intrepid research. Theory into Practice, 29(3), 131-137.

DuBois, W. E. B. (1994). The souls of black folk. New York, NY: Dover Publications, Inc. Engberg, M., \& Wolniak, G. (2010). Examining the effects of high school contexts on postsecondary enrollment. Research in Higher Education, 51(2), 132-153.

Farmer-Hinton, R. L. (2011). On being college prep: Examining the implementation of a “college for all” mission in an urban charter school. Urban Review, 43,(5), 567-596.

Farmer-Hinton, R. L., \& Adams, T. L. (2006). Social capital and college preparation: Exploring the role of counselors in a college prep school for black students. Negro Educational Review, 57(1-2) 101-116.

Freire, P. (2009). Pedagogy of the oppressed. New York, NY: The Continuum International. Garfinkel, H. (1967). Studies in ethnomethodology. Englewood Cliffs, NJ: Prentice-Hall. Guess, T. J. (2006). The social construction of whiteness; Racism by intent, racism by consequence. Critical Sociology (13)4, 649-673. 
Hagedorn, L. S. \& Fogel S. (2002). Making school to college programs work: Academics, goals and aspirations. In W.G. Tierney \& L.S. Hagedorn (Eds.), Increasing access to college: Extending possibilities or all students (pp. 169-193). Albany, NY: State University of New York Press.

Harper, S. R., Patton, L. D., \& Wooden, O. S. (2009). Access and equity for African American students in higher education: A critical race historical analysis of policy efforts. The Journal of Higher Education, 80(4), 389-414.

Hatt, B. (2012). Smartness as a cultural practice in schools. American Educational Research Journal, 49(3), 438-460.

Heller, D. E. (2013). The role of finances in postsecondary access and success. In L.W. Perna \& A.P. Jones (Eds.), The state of college access and completion: Improving college success for students from underrepresented groups (pp.10-33). New York, NY: Routledge.

Hoffman, N., Vargas, J., \& Santos, J. (2009). New directions for dual enrollment: Creating stronger pathways from high school through college. New Directions for Community Colleges, 145, 43-58.

Holland, N. (2011). The power of peers: Influences on postsecondary education planning and experiences of African American students. Urban Education, 46, 1029-1055.

hooks, b. (1994). Teaching to transgress: Education as the practice of freedom. New York, NY: Routledge.

Ishitani, T. T. (2006). Studying attrition and degree completion behavior among first-generation college students in the United States. The Journal of Higher Education, 77(5), 861-885. 
Jayakumar, U. M., Vue, R., \& Allen, W. R. (2013). Pathways to college for young black scholars: A community cultural wealth perspective. Harvard Educational Review, 83(4), 551-579.

Karen, D. \& Dougherty, K. J. (2005). Necessary but not sufficient: Higher education as a strategy of social mobility. In G. Orfield, P. Marin \& C. L. Horn (Eds.), Higher education and the color line: College access, racial equity and social change (pp. 33-58). Cambridge, MA: Harvard Education Press.

Kozol, J. (2010). Savage inequalities: Children in America's schools. New York, NY: Broadway Books.

Kurleander, M. \& Flores, S. M. (2005). The racial transformation of higher education. In G. Orfield, P. Marin \& C. L. Horn (Eds.), Higher education and the color line: College access, racial equity and social change (pp. 11-32). Cambridge, MA: Harvard Education Press.

Ladson-Billings, G. (1999). Just what is critical race theory, and what's it doing in a nice field like education? In L. Parker, D. Deyhle \& S. Villenas (Eds.), Race is...Race isn't: Critical race theory \& qualitative studies in education (pp.7-30). Boulder, CO: Westview Press.

Ladson-Billings. (2006). From the achievement gap to the education debt: Understanding achievement in U.S. schools. Educational Researcher, 35(7), 3- 12.

Long, B. T. (2013). Supporting access to higher education. In M. J. Bailey \& S. D. Anziger (Eds.), Legacies of the War on Poverty (pp.93-120). New York NY: Russel Sage Foundation.

Levine, R. A. (1970). The poor ye need not have with you. Cambridge, MA: The M.I.T. Press. 
Lleras, C. (2008). How do skills and behaviors in high school matter? Contribution of noncognitve factors in explaining differences in educational attainment and earnings. Social Science Research, 37(3), 888-902.

Mathison, S. (1988). Why triangulate? Educational Researcher, 17(2), 13-17.

Maxwell, J. A. (2002). Understanding and validity in qualitative research. In A. M. Huberman \& M. B. Miles (Eds.), The qualitative researcher's companion. (pp. 37-64). Thousand Oaks, CA: Sage Publications.

Menchaca, M. (1997). Early racist discourses: Roots of deficit thinking. In R. Valencia (Ed.), The evolution of deficit thinking: Educational thought and practice (pp. 1-12). Washington, DC: The Falmer Press.

Merriam, S. B. (2009). Qualitative research: A guide to design and implementation. San Francisco, CA: Jossey-Bass.

Moore, R. B. (2001). Racist stereotyping in the English language. In M. L. Anderson \& P. H. Collins (Eds.), Race, class, and gender: An anthology (4th ed., pp. 322-333). Belmont CA: Wadsworth/Thomas Learning.

National Center for Education Statistics (2017). http://nces.ed.gov/fastfacts/display.asp?id=72 Pascarella, E. T., Pierson, C. T., Wolniak, G. C., \& Terenzini, P. T. (2004). First-generation college students: Additional evidence on college experiences and outcomes. Journal of Higher Education, 75(3), 249-284.

Patton, L. (2016). Disrupting postsecondary prose: toward a critical race theory of higher education. Urban Education (51)3, 315-342. 
Perna, L. W. (2005). The key to college access: Rigorous academic preparation. In W. G. Tierney, Z. B. Corwin \& J. E. Colyar (Eds.), Preparing for college: Nine elements of effective outreach (pp. 113-134). Albany, NY: State University of New York Press.

Perna, L. W. \& Titus, M. A. (2005). The Relationship between parental involvement as social capital and college Enrollment: An examination of racial/ethnic group differences. Journal of Higher Education.76(5), 485-518.

Perna, L. W., Rowan-Kenyon, H., Bell, A., Thomas, S. L., \& Chunyan, L. (2008). A typology of federal and state programs designed to promote college enrollment. The Journal of Higher Education, 79(3), 243.

Perna, L. W. \& Kurban, E. R. (2013). Improving college access and choice. In L. W. Perna \& A. P. Jones (Eds.), The state of college access and completion: Improving college success for students from underrepresented groups (pp.10-33). New York, NY: Routledge.

Reid, M. J. \& Moore III, J. L. (2008). College readiness and academic preparation for postsecondary education: Oral histories of first generation urban college students. Urban Education, 43(2), 240-261.

Rodgers, K. A., \& Summers, J. J. (2008). African American students at predominantly white institutions: A motivational and self-systems approach. Educational Psychology Review, 20, 171-190.

Bouffard, S. M. \& Savitz-Romer, M. (2012). Ready willing and able. Educational Leadership, 40-43.

Shapiro, J. P., Sewell, T. E. \& Ducette, J. P. (1995). Reframing diversity in education. Lanham, MD: Scarecrow Press. 
Sokatch, A. (2006). Peer influence on the college-going decisions of low socioeconomic status urban youth. Education and Urban Society, 39(1), 128-146.

Strauss, A. L. \& Corbin, J. M. (1998). Basics of qualitative research: Techniques and procedures for developing grounded research ( $2^{\text {nd }}$ ed.). Thousand Oaks: Sage.

Swail, W. C. (2005). Value added: The costs and benefits of college preparatory programs in the Unites States. In W. G. Tierney, Z. B. Corwin \& J. E. Colyar (Eds.), Preparing for college: Nine elements of effective outreach (pp. 173-199). Albany, NY: State University of New York Press.

Thompson, A. (2001). Summary of whiteness theory. Retrieved from http://www.pauahtun.org/Whiteness-Summary-1.html

United States Department of Education. (2015). Fast facts. National Center for Education Statistics Retrieved from https://nces.ed.gov/fastfacts/display.asp?id=27

Valencia, R. (1997). Conceptualizing the notion of deficit thinking. In. R. Valencia (Ed.), The evolution of deficit thinking: Educational thought and practice (pp. 1-12). Washington, DC: The Falmer Press.

Villalpando, O. \& Solorzano, D. G. (2005). The role of culture in college preparation programs: A review of the research literature. In W. G. Tierney, Z. B. Corwin \& J. E. Colyar (Eds.), Preparing for college: Nine elements of effective outreach (pp. 13-28). Albany, NY: State University of New York Press.

Vine, P. (1976). The social function of eighteenth-century higher education. History of education quarterly, 16(4), 409-424. 
Walpole, M. (2008). Emerging from the pipeline: African American students, socioeconomic status, and college experiences and outcomes. Research in Higher Education, 49(3), 237255.

Welner, K. G., \& Carter, P. (2013). Achievement gaps arise from opportunity gaps. In P. L. Carter \& K. G. Welner (Eds.), Closing the opportunity gap: What every American must do to give every child an even chance (pp. 1-10). New York, NY: Oxford University Press.

Welton, A. D., \& Martinez, M. A. (2014). Coloring the college pathway: A more culturally responsive approach to college readiness and access for students of color in secondary school. Urban Review, 46, 197-223.

Winkle-Wagner, R. (2010). Cultural capital: The promises and pitfalls in educational research. Ashe Higher Education Report, 36(1).

Woodson, C. G. (1998). The education of the Negro. Brooklyn, NY: A\&B Publishing Group.

Woodson, C. G. (2013). The mis-education of the Negro. Lindenhurst, NY: Tribeca Books

Young, A., Johnson, G., Hawthorne, M., \& Pugh, J. (2011). Cultural predictors of academic motivation and achievement: A self-deterministic approach. College Student Journal, 45(1), 151-163.

Yosso, T. J. (2005). Whose culture has capital? A critical race theory discussion of community cultural wealth. Race, ethnicity and education. 8(1), 69-91. 


\section{APPENDIX A: INTEERVIEW PROTOCOL}

1. Tell me a little bit about yourself.

2. Tell me about your experiences with college access.

3. Tell me how you came to this work.

4. Describe the students that your program serves and their needs?

5. Tell me about your program mission.

6. What are the goals and objectives of your program?

7. What have been some of your program successes? Challenges?

8. As a program leader what have been some of your challenges implementing the program goals?

9. What are the funding guidelines of the program?

10. Does your vision differ from the stated program mission, vision, goals and objectives?

11. Tell me about how the process for program development? What elements inform programming (academic research, grant objectives, tradition, school curricula)?

12. How often do you engage students during the program year? What do you do?

13. How do you go about serving individual student needs - e.g. academic, cultural, social, and emotional?

14. What outside forces effect the students' postsecondary aspirations? In what ways does your program address or alleviate these issues?

15. What would program leaders, staff and participants say about the overall effectiveness of the program activities?

16. Describe a student who is considered a program success. 
17. Are there any perceived limitations in meeting program objectives? How do you navigate those limitations?

18. If resources were not an issue what would you add to the program? What would you take away? 


\section{APPENDIX B: RECRUITMENT EMAIL}

Greetings,

I am a doctoral student at Illinois State University, currently completing my dissertation with Dr. Pamela Hoff in the College of Education. I am conducting a research study to explore the perceptions of college access program directors on program goals and effectiveness. This study seeks to identify best practices for college access programs in ensuring participants' college success.

I am requesting your participation, which will involve an interview, sharing of documents related to the administration of your program, and two observations of your normal work day. The interview with me will take place at a location convenient to you, and last about 45-60 minutes. The observations will take place in your work setting and may include meetings as well as scheduled program activities. With your permission, the interview will be audiotaped. The information obtained from the documents collected, and during the interview, will contribute to obtaining clear perceptions of your program operations.

Your participation is voluntary. If you would like to be a part of this research study, please respond to this email. I will call you within 1-2 days to set up a convenient time for the interview.

Thank you very much for your time and interest in this study. Your opinions will be invaluable to the success of this research study.

Sincerely,

Jillian Havard 